\title{
Experimental Research on the Origin of Leukemo- and Carcino-genesis from the Viewpoint of Cell-genetics and Virus
}

\author{
By \\ Isamu Awano, Shin Toshima, Fukumi Tsuda, Hiroshi Sato, \\ Shigeru Matsuyama and Kazuhiko Kokubun
}

\author{
The First Department of Internal Medicine, Fukushima Medical \\ College, Fukushima; Director: I. A wa no
}

(Received for publication, February 29, 1964)

Experiments were carried out in 9 cases of AKR- and C58-mouse leukemia and in 5 cases of $\mathrm{C} 3 \mathrm{H}-$, C58-, and dd-mouse mammary cancer in order to make the cause and mechanism of leukemo- and carcino-genesis from the viewpoint of cell genetics and virus. The results obtained from the present studies lead to the following conclusion.

1) From the results based on our chromosomal studies in the mouse leukemias and mammary cancers, it is considered that even neoplastic cells are possessed of a difinite chromosomal arrangement and they are divided by regular mitosis and also that the fundamental change in malignant cells would be existent in the genetic component of neoplastic cells.

2) The virus particles were detected in the neoplastic tissue of all the cases of spontaneous leukemias and mammary cancers and even in that of the $\mathrm{X}$-ray induced leukemia, and viral origin of leukemo-genesis are shown by the results of transplantation with cell-free leukemic extracts.

The phenomenon of the disappearance of virus from the leukemic tissue of longterm transplanted leukemia and that of virus induction under the influence of $\mathrm{X}$-ray irradiation suggest that the virus is directly linked with the chromosome as a provirus and take a direct part in the nuclear division of neoplastic cell.

3) Nuclear involvement of virus was found in the leukemic cells and in the mammary cancer cells in mitosis or in resting stage.

4) The origin of the tumor virus in these leukemias and mammary cancers were investigated and it was found that viruses were existent even in the mammary gland of healthy $\mathrm{C} 3 \mathrm{H}$-mice and in the thymus tissue of healthy AKR. mice.

The knowledge concerning the cause of leukemo- and carcino-genesis is still meager at present, though many hypotheses such as abnormal metabolism, tumorinducing chemical agents, biological effect of radiation, endocrine, and others have now been proposed by many investigators.

粟野亥佐武，外島 伸，津田福視，佐藤 宏，松山茂，国分一彦 
In recent years two apparently opposite theories, the mutation theory and the viral one, have come into the limelight as expounding the causes of the carcinogenesis. The recent development of cytological techniques for chromosomal studies, particularly in mammalian cells, has contributed a great deal to the investigation in the development of malignant tumors, and various facts on the chromosomes of neoplastic cells have been revealed recently.

On the other hand, the eausal relationship between cancer and virus was for the first time experimentally established in 1908 by Ellermann and Bang ${ }^{14}$ ) in their work on the transmission of fowl leukemia by means of cell-free preparation.

During the thirty years following the discovery of avian neoplastic virus, many investigators, such as Raus, Fujinami and Furth, Shope, Bittner, and others, stressed the viral etiology of tumor. But unfortunately these important experiments failed to have much impact on contemporary investigators. Following Gross's revelation of the viral factor in the etiology of spontaneous leukemia of mice ${ }^{23,24)}$, the virology in the field of neoplasm has made considerable development.

In the last decade, Friend ${ }^{16)}$, Beard 7 , Molony ${ }^{40)}$, Dmochowski ${ }^{12,13)}$ and other researchers have made reports on the viral etiology in reference to the leukemo- and carcino-genesis in mice and rats. In their viral concept, the primary determinant of malignancy is an element external to the cell. This conceptual distinction in two theories between heredity and infection has appeared irreducible until recently.

As a consequence of the recent development of bacteriogenetics, however, the concepts of heredity and infection no longer appear irreconcilable. The lysogenic bacteria is the known example of integration of the genetic material of a virus into the genetic apparatus of the host at the chromosomal level and the examples brought to light in the study of bacterial genetics might serve as significant models in the analysis of cancer genesis. However, in the case of malignant neoplasm the relationship of such integrated viruses with the genetic component is still unknown.

The present experimental studies were carried out for the investigation of the mechanism of leukemo- and carcino-genesis from the fields of virology and cellgenetics.

\section{MATERIALS AND METHODS}

The material used for the present experiments consisted of eight thymic leukemias induced in AKR-mice (high leukemia strain), one lymphoid leukemia induced in C58-substrain mice (low leukemia strain; the incidence of leukemia in this strain is less than $1 \%$ ), three mammary cancers induced in $\mathrm{C} 3 \mathrm{H} / \mathrm{HeN}$ (high mammary cancer strain), one C58 substrain mouse mammary cancer (low mammary cancer strain) and one dd-mammary cancer, and they were all of spontaneous 
origin.

The leukemic tissue and the cancer tissue used for chromosomal studies were obtained from the fresh tissue of lymph gland, thymus, spleen, solid tumor, peripheral blood and ascites in leukemic mice, and also from tumor tissue in mammary cancer in mice. The technique applied to the chromosomal studies was done by squash method as follows;

For observation of the chromosomes of neoplastic cells in solid tumor, a small piece of tumorous tissue was minced on clean slide and hypotonic solution (a mixture of equal volume of 0.001 normal salt solution and 0.01 normal $\mathrm{CaCl}_{2}$ solution) was added to the material and after having been left alone for about 10 minutes, the material was stained with acetic orcein solution (1.5 per cent orcein in 40 per cent acetic acid) for 10 to 15 minutes in proportion to the volume of tissue. Squashing was done by applying an even pressure on the coverslips with a thumb. For observation of the chromosomes of neoplastic cells in ascites or peripheral blood, the cell suspension was pretreated with hypotonic solution for about 10 minutes prior to the application of acetic orcein solution.

For the electron microscopic observation of virus, mammary cancer tissue and leukemic tissue (lymph gland, thmus, spleen) were fixed in one per cent osmium tetroxide in veronal acetate buffer $(\mathrm{pH} 7.4)$ for 2 hours at $2^{\circ}-5^{\circ} \mathrm{C}$, dehydrated in graded concentration of ethanol. In some cases they were embedded in mixture of methyl and butyl metacrylates in the proportion of $1: 1$, and in other cases they were embedded in epon (a mixture of epon 815 and epon 812 in the proportion of $7: 5$ ). Sections were cut with a glass knife on a microtome and to enhance the contrast, some sections were floated on lead acetate and other sections were floated on 1 per cent potassium permanganate solution for about 5 minutes, next on 5 per cent citric acid solution for 40 seconds and then on $2-5$ per cent uranyl acetate solution for about 2 hours.

For the experimental study of transmission with cell-free filtrate the leukemic tissue of spleen, lymph gland, and thymus were used for the recovery and concentration of leukemia virus. For the preliminary extraction, 10 percent homoginate of leukemic tissue in physiological salt solution was cleared of nuclei and cell fragments by low-speed centrifugation. The supernatant fluid recovered from this run was used for transmission after following two different procedures. For the transmission with cell-free filtrate of the AKR-leukemias, the supernatant fluid was cleared of cellular material by its passage through a Berkefeld N. Filtrate was used for isologous transmission, intravenously, subcutaneously and intraperitoneously.

For the transmission with cell-free extracts of the C58 leukemias the supernatant fluid was cleared of cellular material once more by centrifugation at 3.000 r.p.m. for about $20-30$ minutes. Supernatant fluid from this run was used for inoculation with the same strain mice. 


\section{RESULTS AND REMARKS}

1. Chromosome status in the spontaneous, primary and transplanted leukemias and mammary cancers

An abnormal chromosome constitution was postulated by Boveri to be aprimary cause of malignant change in cells. Recently by employing the modern method for chromosome analysis, a great amount of informations concerning chromosome constitution and behavior of malignant cells in mammals have been accumulated by a number of investigators, including Hauschka 1961 25), Levan 1956 $6^{\text {31-33), }}$ and Makino $1957^{37-39)}$.

In these informations, it is reported that many tumor cells are composed of population of cells which have changed from normal tissue cells not only in their chromosome number but also frequently in their chromosome pattern.

It is still undetermined, however, whether the numerical and structural variations observed in the chromosome status of oneplastic cells are a primary event of neoplastic transformation or only a secondary phenomenon. In the present studies, to test this point, $8 \mathrm{AKR}$ leukemias, one C58 leukemia and $4 \mathrm{C} 3 \mathrm{H}$

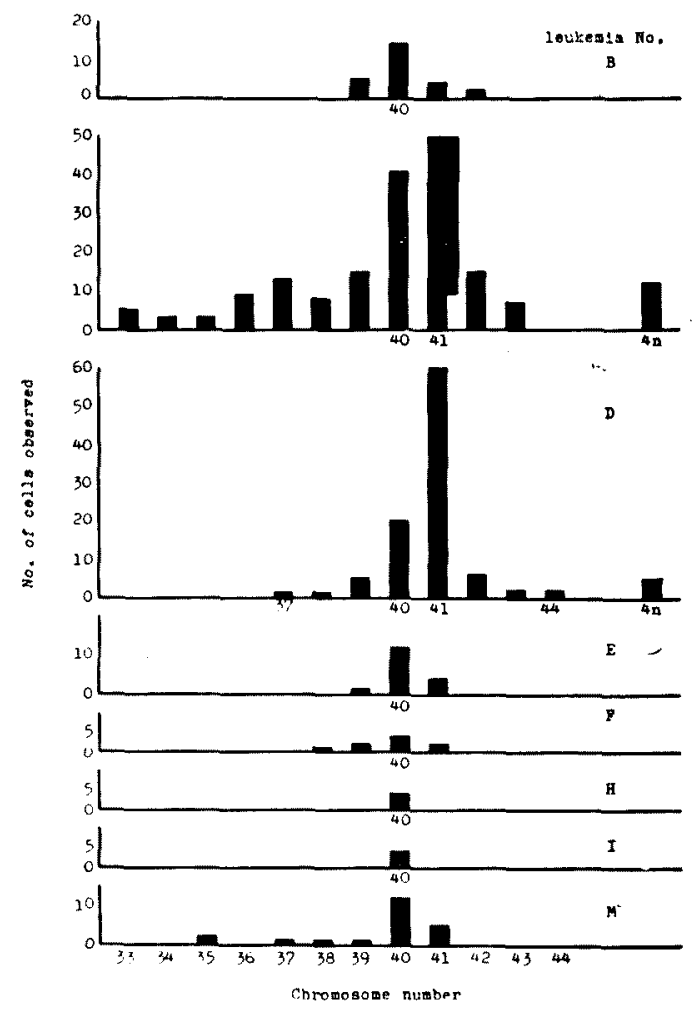

Fig. 1. The chromosome number distribution in 8 AKR-leukemias of spontaneous origin. 
mammary cancers of spontaneous primary origin, were first subjected to cytological analysis.

In 6 AKR leukemias, the modal chromosome number was 40 , but in two cases it was 41 as shown in Fig. 1. In mouse mammary cancers, in 2 cases it was 40 in modal number, but in another case (1st transplanted generation) it was 39 and in the remaining one of $\mathrm{C} 3 \mathrm{H}$ mammary cancer, there were two modes, 37 and 40 , as shown in Fig. 2.

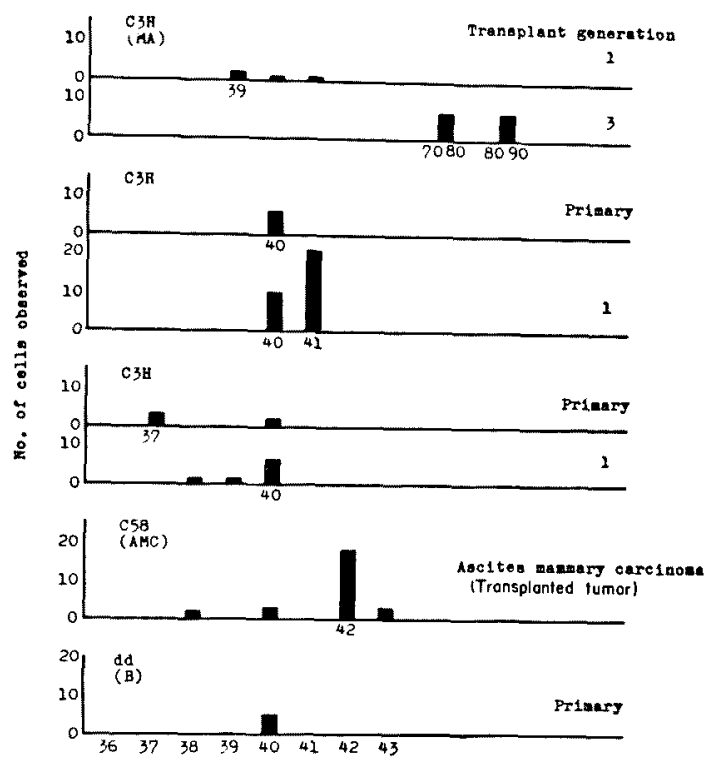

Fig. 2. The chromosome number distribution in 5 mammary cancers of spontaneous origin and transplanted one.

The chromosome pattern of neoplastic cells in these leukemia and mammary cancers was generally composed of acrocentric chromosomes identical with those of somatic tissue.

Therefore, gross chromosomal alteration was not generally observed in the neoplastic cells in these spontaneous primary leukemias and mammary cancers, though there was a wide variation range in chromosome number and sometimes aneuploid cells were also existent as stem-cells, especially in mammary cancers.

The chromosome status in neoplastic tissue of transplanted leukemias and mammary cancers, was next investigated. Results are shown in Figs. 3 and 4.

The karyotypes of these neoplastic cells were not easily altered through the serial transplantations. For instance, the chromosome number distributions of AKR-leukemia No. B in each generation of transplantation are shown in Fig. 3. The karyotype of stem-cells is generally passed on in toto to the 

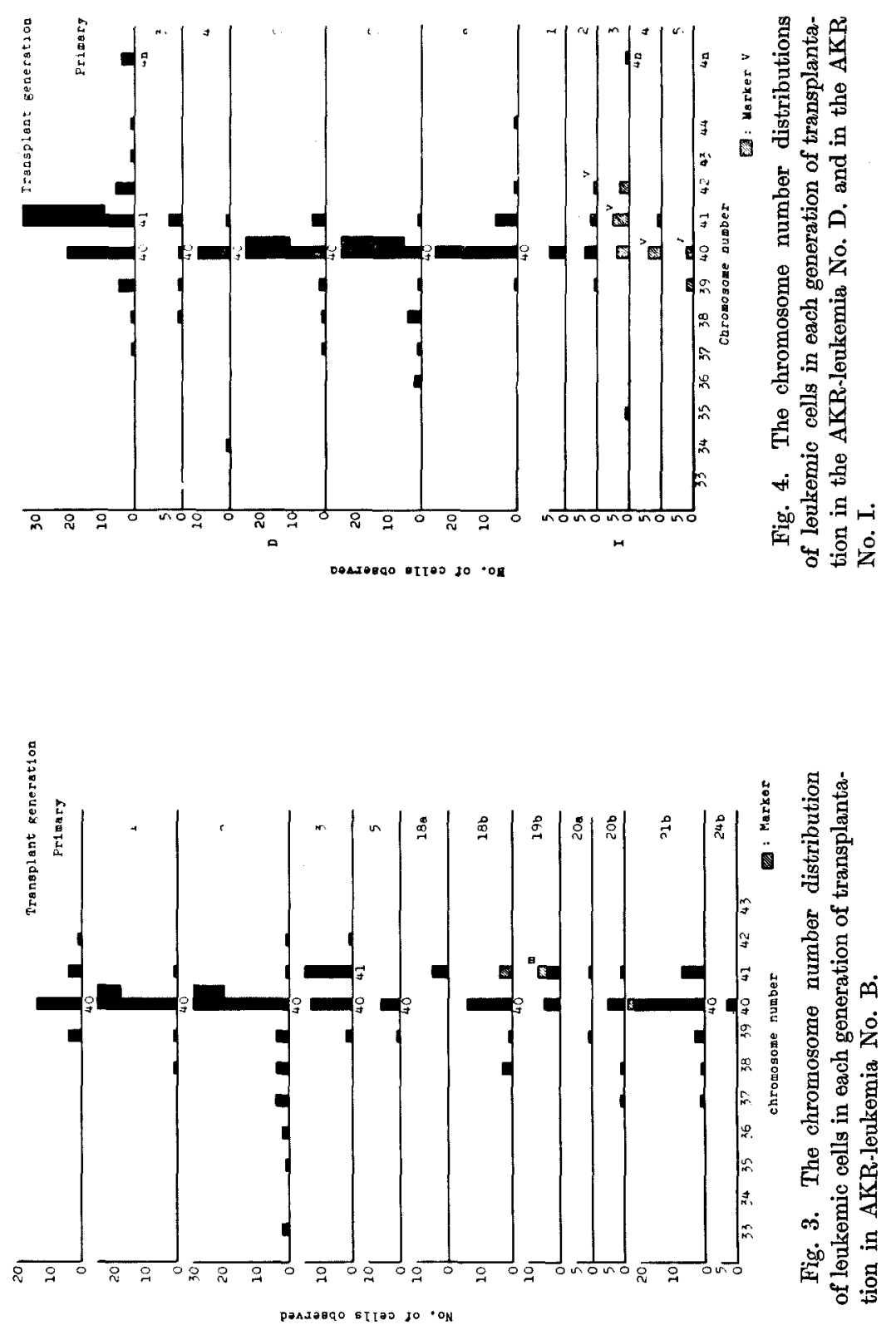
successive generations.

At times, however, the karyotype shows a sudden change through transplantation, especially in the early generation of serial transplantation. In the 3rd generation in this transplanted leukemia, there are two modes in chromosome number, 40 and 41 , and in the 18th generation a minute chromosome appears in some leukemic cells and two kinds of leukemic cells are present in mosaic in this generation as shown in Fig. 1 in Plate 1.

The chromosome number in another spontaneous AKR-leukemia No. D was 41 in primary origin, but this number changed into euploid number at the 4th transplanted generation. In another AKR-leukemia No. I a metacentric chromosome appeared in the karyotype of some leukemic cells at the 2 nd generation and the majority of cells acquired this marker at the 3rd generation as shown in Fig. 4, and in Plate 2, though the karyotype of this leukemic cells changed again into a normal one in later generations.

In the case of $\mathrm{C} 3 \mathrm{H}$ mammary cancer No. $\mathrm{MH}$, the basic chromosome number was 39 in the 1st transplanted generation, but this near-diploid number changed into near-tetraploid number at the 3rd transplant generation as shown in Plate 3.

Nevertheless, in disregard of the alteration of chromosome status in transplanted leukemia and mammary cancers, the characteristics of these neoplasms including their transplantability do not apparently undergo any change.

On the other hand, it was observed in the transplanted C58 leukemia that disregarding the alteration of features of leukemia, no change was identifiable in chromosome status. In C58 generalized lymphoid leukemia, the modal chromosome number was 40 in their spontaneous primary origin and the chromosome pattern was composed of acrocentric chromosomes, identical with the somatic cells, though it showed a wide variation range in number. By isologous transplantation of this leukemic cells, all of the recipient mice developed generalized lymphoid leukemia in 4 to 7 days and no chromosomal change was identifiable in the successive generations of transplantation.

In about the 20th transplant generation, however, the chromosomal changes occurred in this leukemia and there appeared two marker chromosomes in the karyotype disregarding no change in feature and transmissibility. One of these marker chromosomes was a minute chromosome and the other was a mediumsized acrocentric chromosome with a secondary constriction as shown in Plate 4.

Once a change occurred in the chromosome pattern, the karyotype of these leukemic cells became more stable and showed no further change up to the present (for over 150 generations of transplantation). Nevertheless, in about the 30 th transplant generation, this leukemia transformed unexpectedly into a solid form by subcutaneous isologous transplantation or into an ascites form by intraperitoneal inoculation with leukemic cells and these three forms of this 
leukemia were capable of being altered to one another. So it was investigated using three forms of this leukemia, whether or not chromosome condition underwent a change with the alteration of leukemia form.

As a consequence of chromosomal analysis it was revealed that either in solid form or in ascites form, the cell population always contained cells with the same karyotype as those of generalized form, and two marker chromosomes were sure to exist in their chromosome pattern as shown in Figs. $4 \mathrm{~b}$ and $4 \mathrm{c}$ in Plate 4.

This fact indicated that the development of these transplanted leukemias were derived from the donor cells used for transplantation regardless of the change in leukemia forms, but not from the somatic cells of the recipient mice, and the neoplastic transformation (metaplasia) of host cell of the recipient mice had no part in the development of these transplanted leukemias.

In this way the karyotype of neoplastic cells together with a characteristic of malignant tumor is perfectly transmitted generally to the successive generations by transplantation. This fact suggests that even neoplastic cells are possessed of a definite chromosomal arrangement in cell division and they are divided by regular mitosis, and it is considered that the fundamental change would be existent in the genetic component of neoplastic cells.

2. Leukemo- and carcino-genesis and virus in mice

A great progress has been made in the study of cell-virus interrelationship in cancer tissue, and many valuable experiments on the tumor virus have been accomplished in the field of electron-microscopic studies (Beard 1957'), Dmochowsky 195712,13), Amano 19581,2), Moore 195941), Bernhard 1958, 19608,9), Haguenau 196024), DeHarven 196011) and others). Little experimental study, however, has yet been made of the relationship between virus and genetic component. From the experimental results based on our chromosomal study of mouse leukemias and mammary cancers as cited above, it is undeniable that the populations of stem-cells which provide a definite karyotype, play a principal role in the development of malignant growth in these neoplasms in mice.

Although this fact suggests that the fundamental changes exist in the genetic component in nucleus in these malignant tumor cells, no indication of nuclear involvement of virus has ever been detected in mouse leukemias or mammary cancers.

Now in the present study, ultrastructural cell-virus relationship in these neoplasms was first taken up and further studied to make clear this important problem of virus-nucleus interrelationship.

i) Ultrastructural virus-cell interrelationship in the mouse-leukemias and mammary cancers

In the present study, the virus particles were detected in the neoplastic tissue in all cases of spontaneous mouse leukemias and mammary cancers of early 
generations of serial transplantation, either in high leukemia and mammary cancer strains or in low leukemia and mammary cancer strains.

Further, the transplantation of leukemias by cell-free leukemic extracts

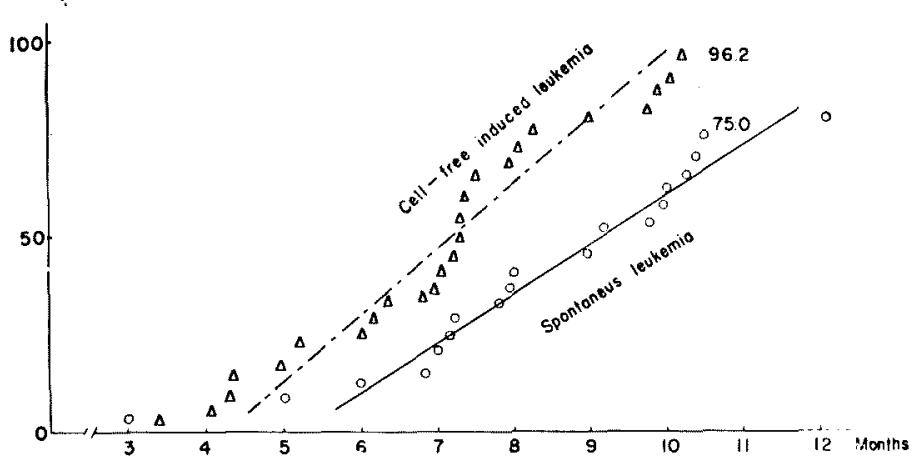

Fig. 5. Cumulative percent deaths of leukemic AKR mice.

TABLE I. AKR Leukemias Induced by Cell-free Leukimic Extracts

\begin{tabular}{|c|c|c|c|c|c|c|c|c|}
\hline $\begin{array}{l}\text { Leukemia } \\
\text { line }\end{array}$ & $\begin{array}{l}\text { Transpl. } \\
\text { gener. }\end{array}$ & $\begin{array}{l}\text { Age of } \\
\text { mice } \\
\text { inoc. }\end{array}$ & $\begin{array}{l}\text { Oncet } \\
\text { period } \\
\text { after } \\
\text { inoc. }\end{array}$ & $\begin{array}{c}\text { No. } \\
\text { positive }\end{array}$ & & $\begin{array}{l}\text { No. } \\
\text { inoc. }\end{array}$ & $\begin{array}{l}\text { Anatomical } \\
\text { diag. }\end{array}$ & $\begin{array}{l}\text { Microscopical } \\
\text { diag. }\end{array}$ \\
\hline B & $\begin{array}{l}\text { Primary } \\
\text { Cell-free } \\
\text { pass. } 1 \\
\\
\text { Cell-free } \\
\text { pass. } 2\end{array}$ & $\begin{array}{c}4.0 \mathrm{mo} \\
" \\
1 . \\
1.5 \\
" \\
" \\
10 \text { days } \\
" \\
" \\
"\end{array}$ & $\begin{array}{l}3.5 \mathrm{mo} \\
" \prime \\
5.5 \\
6.0 \\
" \\
" \prime \\
6.5 \\
4.0 \\
4.5 \\
5.0 \\
6.0\end{array}$ & $\begin{array}{l}4 \\
4\end{array}$ & 1 & $\begin{array}{l}5 \\
4\end{array}$ & $\begin{array}{l}\text { Generalized } \\
\text { thymic } \\
\text { leukemia } \\
\text { " }\end{array}$ & $\begin{array}{l}\text { Lymphoid } \\
\text { leukemia }\end{array}$ \\
\hline C & Primary & $1.5 \mathrm{mo}$ & 8.5 & 2 & 1 & 2 & $"$ & $"$ \\
\hline $\mathbf{E}$ & Primary & $\begin{array}{c}2.0 \\
" 1 \\
" 1 \\
"\end{array}$ & $\begin{array}{l}3.5 \\
6.0 \\
6.0 \\
8.0 \\
8.5\end{array}$ & 5 & 1 & 5 & & \\
\hline $\mathrm{H}$ & Primary & $\begin{array}{c}1.0 \\
" 1 \\
" 1 \\
" 1\end{array}$ & $\begin{array}{l}5.0 \\
5.5 \\
6.0 \\
" 1 \\
" 1\end{array}$ & 5 & 1 & 5 & & \\
\hline I & Primary & $\begin{array}{c}2.0 \\
\|\end{array}$ & $\begin{array}{l}1.5 \\
2.0\end{array}$ & 2 & I & 2 & $\begin{array}{l}\text { Lokalized } \\
\text { nonthymic } \\
\text { leukemia }\end{array}$ & Lymphoma \\
\hline
\end{tabular}


TABLE II. C58 Leukemias Induced by Cell-free Leukemic Extracts

\begin{tabular}{c|c|ccc|c|c|c}
\hline $\begin{array}{c}\text { Transpl. } \\
\text { gener. }\end{array}$ & Method & $\begin{array}{c}\text { No. } \\
\text { postiv }\end{array}$ & $\begin{array}{c}\text { No. } \\
\text { inoc. }\end{array}$ & $\begin{array}{c}\text { Leuk. } \\
\text { inc., } \%\end{array}$ & $\begin{array}{c}\text { Onset period } \\
\text { after inoc. } \\
\text { (days) }\end{array}$ & $\begin{array}{c}\text { Anatomical } \\
\text { diag. }\end{array}$ & $\begin{array}{c}\text { Microscopical } \\
\text { diag. }\end{array}$ \\
\hline $\begin{array}{c}\text { Primary } \\
\text { l }\end{array}$ & ip & 5 & 13 & 38.4 & $50 \sim 90$ & $\begin{array}{l}\text { Generalized } \\
\text { nonthymic } \\
\text { leukemia }\end{array}$ & $\begin{array}{l}\text { Lymphoid } \\
\text { leukemia }\end{array}$ \\
5 & iv & 8 & 15 & 53.3 & $40 \sim 80$ & & \\
\hline $\begin{array}{c}\text { Passages } \\
22\end{array}$ & ip & & & & & & \\
? & & 0 & 25 & 0 & & & \\
30 & iv & & & & & & \\
\hline $\begin{array}{c}\text { Passages } \\
55\end{array}$ & ip & 0 & 36 & 0 & & & \\
60 & iv & 0 & 7 & 0 & & & \\
& sc & 0 & 16 & 0 & & & \\
& & & & & & & \\
\end{tabular}

prepared from the C58 and AKR leukemias of spontaneous origin and of the early generation of transplsntation was also successful as shown in Tables I and II and Fig. 5.

The virus particles in the leukemic tissue are usually observed in the intercellular space and on the cell surface, and few are found in intracellular vacuolus (Figs. 5 and 6 in Plate 5) and they have not usually been found inside cytoplasm, but in the $\mathrm{C} 58$ subline leukemia induced by $\mathrm{X}$-ray irradiation, virus particles were even in the cytoplasm of leukemic cells (Fig. 7 in Plate 6). Further, virus particles were detected in the leukemic tissue of AKR leukemia induced by cell-free leukemic extracts as shown in Fig. 8 in Plate 6.

Besides, other cells such as megakaryocytes or reticulum cells which do not seem to show the malignant proliferation, are frequently virus carriers, as are already pointed out by Amano 19581), Dmochowsky 1958, Bernhard 1958') and De Harven 196211).

In the megakaryocytes which increase in number in the spleen tissue of spontaneous primary leukemia or of cell-free induced leukemias, it was revealed that the mature viruses were massively grouped in the intracellular bounded structure as shown in Fig. 9 in Plate.

In the mammary cancer tissue the usual localities of mature virus are also extracellular, on the cell surface and in the intracellular vacuolus (Figs. 10 and 11 in Plates 7 and 8).

In addition, doughnut-shaped immature viruses consisting of only innershell having two lamellae which are apparently identical with the innershells of the mature A particle (Bernhard) are found in the cytoplasms of cancer cells in resting stage or in mitosis (Figs. 12 and 13 in Plates 8 and 9).

At times, immature viruses with a circinate innershell or a C-shaped in- 
Origin of Loukemo- and Carcino-genesis

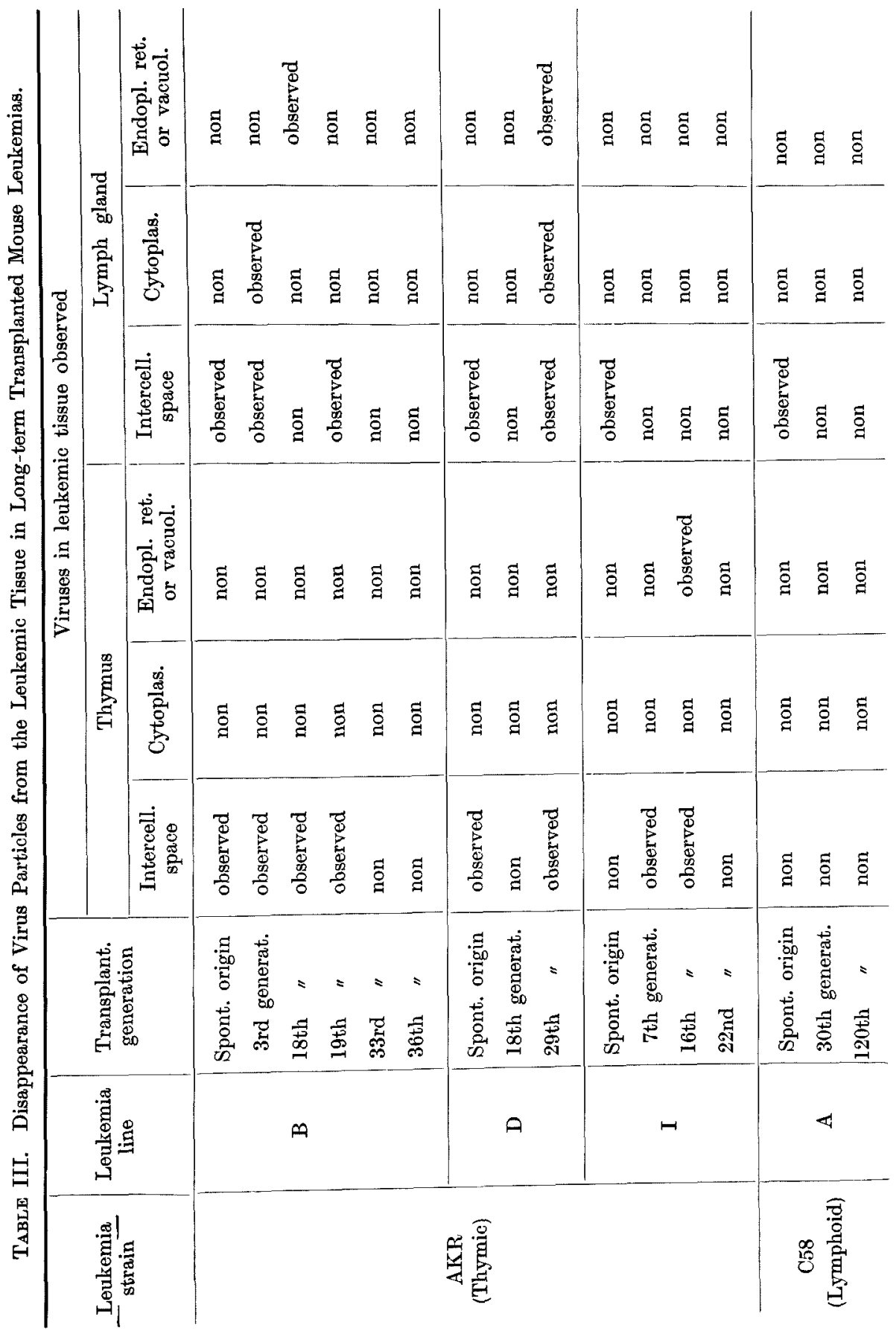


nershell, accompanied by a good many usual immature viruses (immature A particles), were observed as shown in Figs. 14 and 15 in Plate 10. Further, immature viruses with a hazy outlined innershell (the most immature A particle) which is smaller than a usual immature A particle, are also found in the matrix in cytoplasma together with a common immature virus and with a few mature A particle, as shown in Fig. 16 in Plate 10.

These several features of viruses would most probably represent the respective phases in a viral cycle, and the hazy outlined immature A particles seem to represent the earliest phase in this viral cycle. Frequently mature viruses can be observed in the inclusion bodies limited clearly by membrane (Figs. 17 and 18 in Plate 11) and besides, inclusion bodies in which only hazy outlined im mature viruses are present, are also found in cytoplasma of mammary cancer cells (Fig. 19 in Plate 11).

Thus the virus particles were detected in the neoplastic tissues of all cases of these spontaneous mouse leukemias and mammary cancers and even in those of X-ray induced leukemias of low leukemia strain mice, and a viral origin of leukemogenesis is demonstrated by the transmission of AKR- and C58-leukemic cell-free extracts.

The results of the present studies of chromosome and virus in these leukemias and mammary cancers seem to indicate that the genetical change arises probably on account of the cells taking nucleic acid of virus and that must be involved in the neoplastic transformation.

Generally, however, the virus particles were not detected in the nucleus of these malignant tumor cells. Moreover, to my surprise, after the long-term repeated transplantation of these leukemias, the virus particles disappeared from the leukemic tissue in spite of there being no change in the characteristics and transmissibility of these leukemias, and at the same time the transmission with cell-free extracts also proved impossible.

It follows from this that in the long-term transplanted leukemias, the virus production in a cell is not necessary for proliferation of leukemic cells and these leukemic cells are considered to have a karyological contrivance of autonomous malignant growth. However, the X-ray irradiation of the whole body of C58 subline mice which were transferred isologously by leukemic cells of long-term transplanted leukemia devoid of virus, led once again to the detection of viruses in the leukemic tissue of induced leukemias as shown in Fig. 20 in Plate 11.

This phenomenon of induction of virus under the influence of $\mathrm{X}$-ray irradiation can be compared to the virus-cell relationship in lysogenic bacteria, and it is considered from various facts of this study that virus is directly linked with the chromosome as a provirus and takes a direct part in the nuclear division in mitosis of the neoplastic cells. 
ii) Ultrastructural virus-nucleus interrelationship in the mouse leukemias and mammary cancers

The nature of lysogeny and its genetic significance have been fully appreciated by Lowoff and his associates $(1950)^{35,38}$. But no indication of involving virus in the genetic component has ever been proved in the neoplastic cells such as leukemic- or mammary cancer cells.

In the present studies, virus particles are also difficult to find out in the nucleus of the neoplastic cells, though they are usually found in extracellular, on the cell surface, in the vacuolar space, and in cytoplasma of mammary cancer cells. Unexpectedly, however, the particles which seemed to be the most immature viruses were found in the nucleus of leukemic cells of spontaneous primary AKR-leukemia as shown in Fig 21 in Plate 12.

This finding seems to be very important for us to understand the virus-cell interrelationship in a process of leukemogenesis, and this seems to indicate the possibility of involving virus in the genetic component of the nucleus of neoplastic cells. In this case, two chances can be theoretically thought of as for the possibility of involving cytoplasmic immature viruses or extracellular mature viruses into the nucleus. One is a chance of involving immature virus into the nucleus in the stage of metaphase in which there is a possibility of involving cytoplasmic contents in the nucleus even in the normal division cells as shown in Fig. 22 in Plate 12. And the other is a chance of involving mature virus into nucleus through endoplasmic reticulum route.

Now it was found that the cytoplasmic immature viruses embosomed with chromosomes were scattered in the nuclear contents in the metaphasic stage of division cell of $\mathrm{C} 3 \mathrm{H}$ mammary cancer as shown in Fig. 23 and that the mature virus was attached with nuclear membrane in the resting stage of $\mathrm{C} 3 \mathrm{H}$ mammary cancer cells as shown in Fig. 24 in Plate 13. Although it was not always determined whether these viruses are of intranuclear origin or extranuclear one, at any rate, these findings seem to show close relationship between virus and nucleus in the neoplastic cells.

Consequently, from the experimental results of the present studies of chromosome and virus, the genesis of these malignant tumors in mice is thought to proceed on, as indicated in Fig. 6. When the host cells are infected with a tumor virus, they undergo two different series of events. One is the infectious phase in which there have been observed the production of infectious particles and the destruction of infected cells like a lytic cycle in bacteriophage and the other is the malignant phase in which virus is linked with chromosome as a provirus like a lysogenization in lysogenic bacteria.

After long-term repeated serial passages, the disappearance of virus particles from the neoplastic tissue can be seen by the domination of cells in provirus state (malignant phase). The transition from the provirus to the infectious 
state can be induced by exposure of neoplastic cells in malignant phase to physical and chemical agents such as X-ray irradiation and others.

3. Origin of tumor virus in mice

Although it was possible to find out the virus particles in all spontaneous leukemias and mammary cancers examined and even in X-ray induced leukemia in low leukemia strain mice, the origin of the tumor viruses remains still unknown. It is well established that the tumor-inducing activity appears in the milk of high mammary-cancer strain mice long before there are any gross manifestation of tumors in the breast.

Andervout et al. (1942) have found that the activity is transmitted by splenic and normal mammary gland tissue of high cancer strain female. But it has been stated by Dmochowski that no virus particles were seen in the organ of normal young mice of either the AKR, C58 or C3H strain, though characteristic virus particles were revealed in the leukemic organ of high leukemia strain mice (AKR and C58).

In recent years, however, the consistent occurrence of virus particles in preneoplastic hyperplastic mammary tissue of virus-carrying mice or of several strains of apparently virus-free mice has been observed by Pitelka, De-Ome and Bern $(1960)^{43}$.

On the other hand, it has been reported by Kotin ${ }^{30)}$ (1962) that squamous carcinomas were induced in C58 mice after successive infection with influenza virus and there are several works in which other infectious viruses were oncogenic. So it is becoming more and more important to examine whether the viruses found in these mouse leukemias and mammary cancers are those of exogeneous origin or a specific group of viruses with oncogenic properties which inhabit in the tissue of healthy mice.

So the search for viruses from the mammary gland tissue of 4-month-aged healthy $\mathrm{C} 3 \mathrm{H}$ female mouse and from thymus tissue of 10-month-aged healthy AKR-female mouse was carried out to make clear this problem.

Then it has been found that virus particles are existent even in the mammary gland tissue of healthy $\mathrm{C} 3 \mathrm{H}$ mouse and in the thymus tissue of healthy AKR-mouse as shown in Fig. 25 and 26 in Plate 14. In mammary gland, the mature viruses were detected in the ductal space and immature viruses were found in the cytoplasma of epithelial cells of duct system. In thymus tissue of a healthy AKR-mouse, the virus particles are found in the intercellular space.

These particles are similar in morphological feature or in size to those found in mammary cancer tissue or in leukemic tissue. So it appears that these viruses which inhabit in normal tissue of mammary gland of $\mathrm{C} 3 \mathrm{H}$ mice and of thymus of AKR mice are considered as a special group of virus with oncogenic properties and these mice harbor the same viruses in a latent state, though 
they are small in number.

It is of great significance that the treatment of healthy low leukemia strain mice (C58 subline) with $\mathrm{X}$-ray irradiation results in production of leukemia with viruses and this fact would seem to show that the stimulation such as X-ray and other accelerates the neoplastic transformation of somatic cells in these mice.

Now the net result of all these experiments would seem to indicate the mechanism of leukemo- and carcino-genesis proceeds as shown in Fig. 6. The

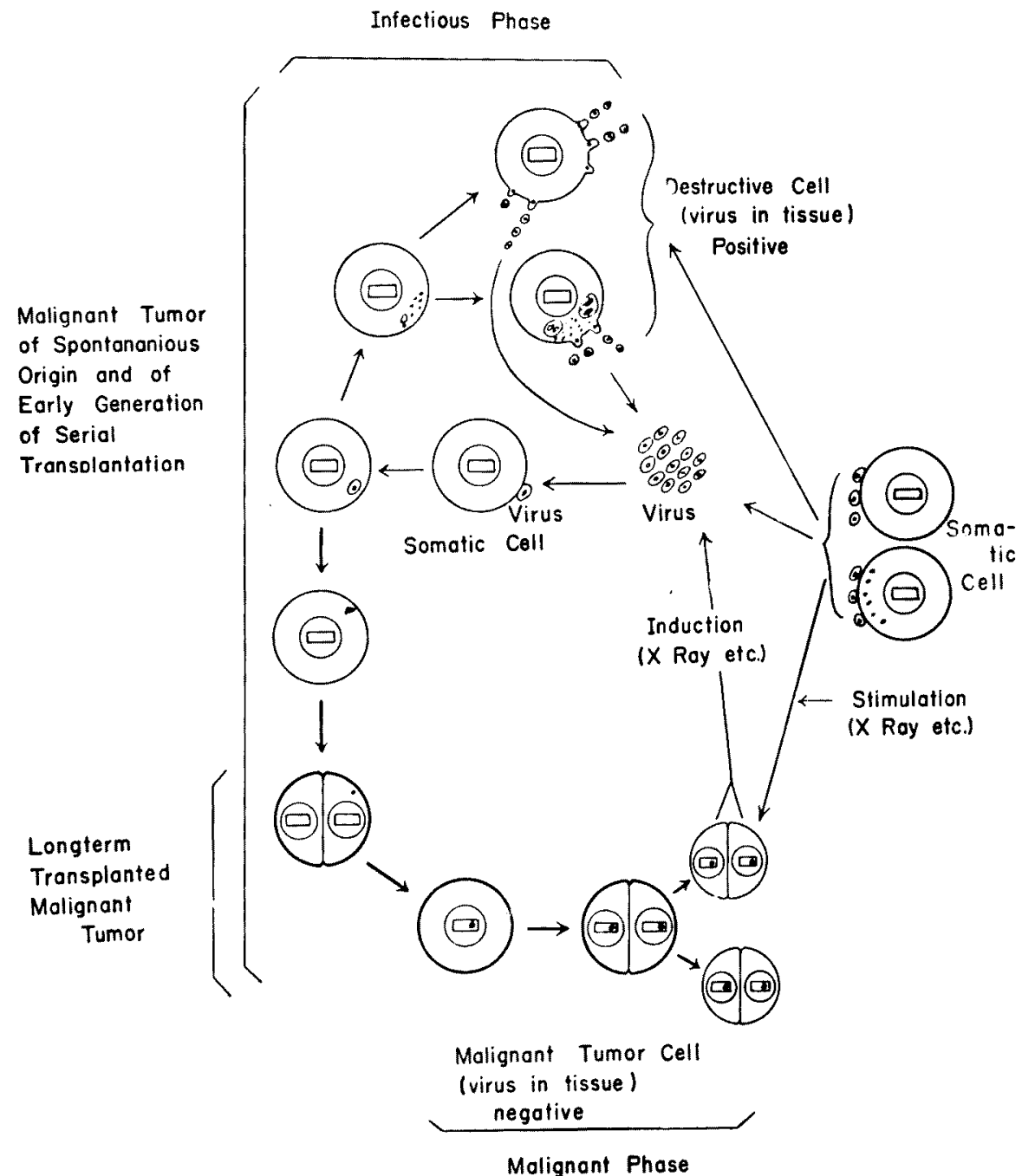

Fig. 6. The process of leukemo- and carcino-genesis from the viewpoint virus and cell genetics. 
reproduced viruses in the healthy mice would seem to play an important role in the neoplastic transformation of somatic cells under the influence of genetical factor as well of environmental factors such as X-ray irradiation or chemical carcinogenic agents and others which act as accelerator.

In this case, it is considered that the virus from healthy mice can then undergo two different series of events. They can either lead the normal somatic cells to the cytological presentation of virus infection, to the destruction of the infected cells and to the production of infectious particles, or they can establish themsevles as a provirus and give rise to a clone of stable malignant tumor cells. It must be born in mind, however, that in the electron microscope picture the existence of virus in the neoplastic tissue does not always mean the neoplastic factor.

\section{COMMENT AND CONCLUSION}

Experiments were carried out in 9 cases of C58- and AKR-mouse leukemia and in 5 cases of $\mathrm{C} 3 \mathrm{H}-$, C58-, and dd-mouse mammary cancers in order to study the cause and mechanism of leukemo- and carcino-genesis from the view-point of cell genetics and virus. The results obtained from the present studies lead to the following conclusion.

1) In general, no gross chromosomal changes have been observed in leukemic and cancer cells in spontaneous primary mouse leukemias and mammary cancers, though there is a wide variation range in chromosome number in these neoplastic cells and some of them have consisted of tumor cells which differed in basic chromosome number from the normal somatic tissue. The karyotypes of these neoplastic cells together with characteristics of malignant tumor were not easily altered through the serial transplantations and they were generally passed on in toto to the successive generation, though at times the karyotypes showed a sudden change through transplantation, especially in the early generations of transplantation.

This fact suggests that even neoplastic cells are possessed of a definite chromosomal arrangment and they are divided by regular mitosis and also that the fundamental change in malignant cells would be existent in the genetic component of neoplastic cells.

2) The virus particles were detected in the neoplastic tissue of all the cases of spontaneous leukemias, and mammary cancers of primary origin and of early generations of transplsntation, either in high leukemia and mammary cancer strains or in low leukemia and mammary cancer strains or even in the leukemia induced by the X-ray irradiation.

The localities of mature viruses in the mammary cancer-and leukemic cells are usually extracellular, on the cell surface, and in the intracellular vacuolus. Moreover, in the mammary cancers, the immature viruses are also found in the 
cytoplasma of cancer cells.

Besides these viruses, the immature viruses with a circinate innershell in company with many usual doughnut-shaped immature viruses and also a few mature viruses, are detected in the cytoplasm of mammary cancer cells. Moreover, the several kinds of cytoplasmic inclusion bodies were detected in the mammary cancer tissue and respective phases in viral circle were presented. Next, the transmission of leukemia by cell-free extracts prepared from the leukemias of spontaneous origin and of the early generations of transplantation was also successful.

This fact indicates that the virus must have a close relation with such a process of leukemo- and carcino-genesis in mice. However, when the serial transplantations of mouse leukemia are repeated for a long period and the chromosome condition becomes more stable, it is found difficult to detect the virus particles in the leukemic tissue, and at the same time the cell-free transmission of leukemia results in failure.

These facts indicate that the virus production in a cell is not necessary for proliferation of leukemic cells and the karyological contrivance manifesting autonomous malignant growth would be existent in the neoplastic cells in the longterm transplanted leukemia. In this case, two questions arise in respect of the relationship between virus and chromosome.

The first is whether the genetic component is only altered by the invasion of virus into neoplastic cells, and the other is whether virus itself is included in the genetic component and takes a direct share in the nuclear division of neoplastic cell. However, it was shown that the X-ray irradiation led to the detection of virus particles once again in the leukemic tissue of long-term transplanted C58leukemia in which virus had disappeared. This phenomenon of induction of virus by X-ray irradiation indicated that the virus is directly linked with the chromosome as a provirus in a lysogenic state, just like a temperate phage in lysogenic bacteria and take a direct part in the nuclear division in the mitosis of a neoplastic cell.

3) Then, the ultrastructural virus-nucleus interrelationship in mouse leukemias and mammary cancers was investigated and it was found that the cytoplasmic immature viruses embosomed with chromosome were scattered in the nuclear contents in the metaphasic stage of division cell of $\mathrm{C} 3 \mathrm{H}$ mammary cancer and that the mature virus was attached with nuclear membrane in the resting stage of $\mathrm{C} 3 \mathrm{H}$ mammary cancer cells.

Further, the particles which seemed to be immature viruses were found in the nucleus of leukemic cells of spontaneous primary AKR leukemia. Many facts obtained from the present studies show that the genesis of these malingant tumors in mice is thought to proceed on as indicated in Fig. 6.

4) The origin of the tumor virus found in these mouse leukemia and mam- 
mary cancers was investigated and it was found that the virus particles were existent even in the mammary gland tissue of healthy $\mathrm{C} 3 \mathrm{H}$ mouse and in the thymus tissue of healthy $A K R$ mouse. It is of great significance that the treatment of healthy low leukemia strain mice (C58 subline) with X-ray irradiation results in the production of leukemia with virus.

This fact would seem to show that the stimulation, such as X-ray irradiation, accelerates the neoplastic transformation as well as virus proliferation In this case, it is considered that the virus from healthy mice can then undergo two different series of events and they can either lead the normal somatic cells to the cytological presentation of virus infection, to the destruction of the infected cells and to the production of infectious particles, or they can establish themselves as a provirus and give rise to a clone of stable malignant tumor cells.

\section{References}

1) Amano, S., Ichikawa, Y. \& Iwakata, S., Acta path. jap., 1958, 8, 615.

2) Amano, S. \& Ichikawa, Y., ibid., 1959, 9, 455.

3) Awano, I. \& Tsuda, F., Jap. J. Gent., 1959, 34, 220.

4) Awano, I., Tsuda, F., Toshima, S. \& Kokubun, K., Tohoku J. exp. Med., 1961, 74, 1.

5) Bayrenuther, K., Nature, 1960, 186, 6.

6) Beard, J.W., Cancer Res., 1956, 16, 279.

7) Beard, J.W., Tex. Rep. Biol. Med., 1957, 15, 627.

8) Bernhard, W., Cancer Res., 1958, 18, 491.

9) Bernhard, W., ibid., 1960, 20, 712.

10) Bernheim, F., Bernheim, M.L.C., Taylor, A.R., Beard, D., Sharp, D.G. \& Beard, J.W., Science, 1942, 95, 230.

11) De Harven, E. \& Fried, C., Nat. Cancer Inst. Monogr., 1960, No. 4, 291.

12) Dmochowski, L. \& Grey, C.E., Ann. N.Y. Acad. Sci., 1957, 68, 559.

13) Dmochowski, L., Grey, C.E., Perarson, L.O., Ward, D.N., Hurlbert, R.B., Griffin, A.C. \& Bresson, A.L., Proc. Soc. exp. Biol., 1959, $102,174$.

14) Ellermann, V. \& Bang, O., Zbl. Bakt. I. Abt. Orig., 1908, 46, 595.

15) Ford, C.E., Hamerton, J.L. \& Mole, R.H., J. cell. comp. Physiol., 1958, 52, (Suppl. 1), 235.

16) Friend, C., $J$. exp. Med., 1957, 105, 307.

17) Furth, J., ibid., 1930, 53, 243.

18) Furth, J., Buffett, R.F., Banasiewicz Rodrignez, M. \& Upon, A. C., Proc. Soc. exp. Biol., 1956, 93, 165.

19) Graffi, A., Ztsch. Ges. Inn. Med., 1958, 13, 961.

20) Greene, H.S.N., Cancer Res., 1954, 14, 463.

21) Greene, H.S.N., ibid., 1955, 15, 748.

22) Gross, L., Proc. Soc. exp. Biol., 1951, 76, 27.

23) Gross, L., Ann. N.Y. Acad. Sci., 1957, 68, 501.

24) Haguenau, F., Bonar, R.A., Beard, D. \& Beard, J.W., J. Nat. Cancer Inst., 1960, 24, 873.

25) Hauschka, T.S., Cancer Res., 1961, 21, 957.

26) Hsu, T.C., Int. Rev. Cytol., 1961, 12, 69.

27) Jacob, F. \& Wallman, E.L., The Virus, Vol.2, Acad. Press, Inc., New York, 1959, p. 319.

28) Kaplan, H.S., Ciba Foundation Symposium Churchill, Ltd., 1959, p. 233.

29) Koller, P.C., Brit. J. Cancer, 1947, 1, 38. 
30) Kotin, P., Prog. exp. Tumor Res., 1963, 3, 187.

31) Levan, A., Ann. N.Y. Acad. Sci., 1956, 63, 774.

32) Levan, A., Exp. Cell Res., 1956, 11, 613.

33) Levan, A. \& Biesele, J.J., Ann. N.Y. Acad. Sci., 1958, 71, 1022.

34) Luria, S.E., Cancer Res., 1960, 20, 677.

35) Lwoff, A., Bact. Rev., 1953, 17, 269.

36) Lwoff, A., The Virus, Vol. 2, Acad. Press, Inc., New York, 1959, p. 187.

37) Makino, S., Int. Rev. Cytol., 1957, 6, 25.

38) Makino, S., J. Fac. Sci. Hokkaido, Ser. VI, Zool., 1957, 13, 263.

39) Makino, S. \& Sasaki, M., J. Nat. Cancer Inst., 1958, 20, 465.

40) Moloney, J.B., ibid., 1960, 24, 933.

41) Moore, D.H., Lasfargues, E.Y., Murray, M.R., Haagensen, C.D. \& Pollard, E.C., J. Biophys. \& Biochem. Cytol., 1959, 5, 85.

42) Orsi, E.V., Love, R. \& Koprowski, H., Cancer Res., 1957, 17, 306.

43) Pitelka, D.P., DeOme, K.B. \& Bern, H.A., J. Nat. Cancer Inst., 1960, 25, 753.

44) Schwartz, S.O., Schoolamn, H.H., Sznts, P.B. \& Spurrier, W., Cancer Res., 1957, 17, 218.

45) Stich, H.F., Waksnig, R. \& Axelrad, A.A., Nature, 1959, 184, 998.

46) Tjio, J.H. \& Ostergren, G., Hereditas, 1958, 44, 451.

47) Waksnig, R. \& Stich, H.F., J. Nat. Cancer Inst., 1960, 25, 295.

\section{LEGENDS FOR FIGURES IN PLATES 1-14}

Figs. la-lc The chromosome complex of leukemic cell in AKR leukemia No. B of primary origin and that in 18th generation of transplantation, ( $\mathrm{m}:$ minute chromosome)

Figs. 2a-2d The chromosome complex of leukemic cells in 2nd-, 3rd-, and 4th generation of transplantation in the AKR leukemia No. I. (v: v-shaped chromosome)

Figs. 3a-3c The chromosome number distribution and chromosome complexes of cancer cells in the I st-and 3rd-generation of transplantation in the $\mathrm{C} 3 \mathrm{H}$ mammary cancer No. MA.

Figs. 4a-4d The chromosome complexes of leukemic cells of three leukemia forms (generalized, solid, and ascites form) in C58 mice in comparison with normal somatic complex. (sc: chromosome with secondary constriction, $\mathrm{m}$ : minute chromosome)

Fig. 5 The virus particles in the lenkemic cell in thymus tissue of the AKR leukemia of spontaneous origin. ( $\mathrm{v}$ : virus particle) $\times 80,000$

Fig. 6 The virus particles on the cell surface of leukemic cell in lymphgland tissue of the AKR leukemia. $\times 82.000$

Fig. 7. Intra-cellular virus particle in the thymus tissue of C58 leukemia induced by $\mathrm{x}$-ray irradiation. $\times 66,000$

Fig. 8 The virus particles observed in the spleen tissue of AKR leukemia induced by cell-free leukemic extracts. $\times 60,000$

Fig. 9 The virus particles in the intra-cellular bounded structure in giant cell in the spleen tissue of AKR leukemia. $\times \mathbf{4 6 , 0 0 0}$

Fig. 10. The extracellular mature virus in the tumor tissue of the $\mathrm{C} 3 \mathrm{H}$ mammry cancer. $\times 75,000$

Fig. 11. The mature viruses in the cytoplasmic vacuolus of the C3H mammary cancer cell. $\times 21,000$

Fig. 12. Immature viruses having only an inner shell (immature A-particls), in the cytoplasm of $\mathrm{C} 3 \mathrm{H}$ mammary cancer cell in resting stage. $\times 48,000$ (C: centriole)

Fig. 13. The immature viruses in the cytoplasm of $\mathrm{C} 3 \mathrm{H}$ mammary cancer cell in mytosis. (Chr.: chromosome) $\times 64,000$

Figs. 14-15. The virus particles having circinate inner shell in the cytoplasm of 
$\mathrm{C} 3 \mathrm{H}$ mammary cancer cell together with a many common immature A particles and with a few mature A particles. $\times 51000$ (CV: virus particles with circinate inner shell.)

Fig. 16. The immature viruses with a hazy outlined inner shell accompained by the common immature A particles and a few mature A particles in the gray matrix without any limited membrane in the C3H mammary cancer cell. $\times 56,000$.

Figs. 17-18. The mature viruses and immature viruses in the cytoplasmic inclusion body limited by membrane, in the cancer cell of $\mathrm{C} 3 \mathrm{H}$ mammary cancer tissue. $\times 84,000$ and $\times 19,000$

Fig. 19. The inclusion bodys comprising only of hazy outlined immature viruses. $\times 56,000$

Fig. 20. The virus particles observed in the lymphgland tissue of long-term transplanted C58 leukemia under the influence of x-ray irradiation. $\times 170,000$

Fig. 21. The hazy outlined virus-like particles in the nucleus of a leukemic cell in resting stage of thymus tissue of $A K R$ leukemia of spontanious primary origin. $\times 63,000$

Fig. 22 The mitochondrias in the nuclear contents of a cell in metaphase in normal thymus tissue of a healthy AKR mouse. $\times 16,000$

Fig. 23 The immatuve viruses embosomed with chromosomes found in a cancer cell in metophase of $\mathrm{C} 3 \mathrm{H}$ mammary cancer tissue. $\times 32,000$

Fig. 24 A mature virus attached with nuclear membrane of $\mathrm{C} 3 \mathrm{H}$ mammary cancer cell. in resting stage. $\times 100,000$

Fig. 25 The virus particles detected in the ductal space and in the cytoplasm of epithelial cell of duct system in normal mammary gland of healthy $\mathrm{C} 3 \mathrm{H}$ mouse. $\times 16,000$

Fig. 26 The virus particles detected in the intercellular space in the normal thymus tissue of healthy AKR mouse. $\times 47,000$ 


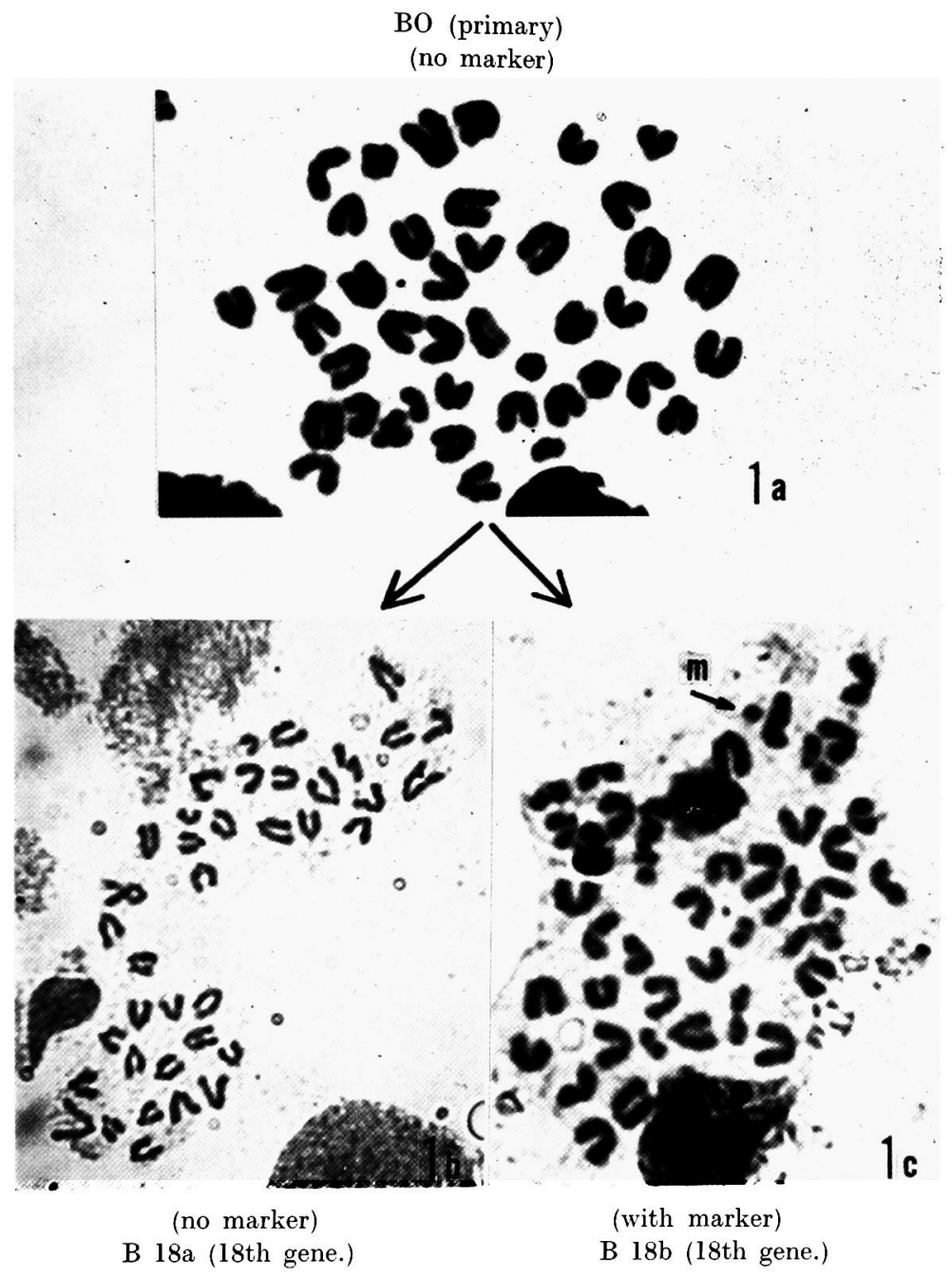

Figs. 1a-lc 


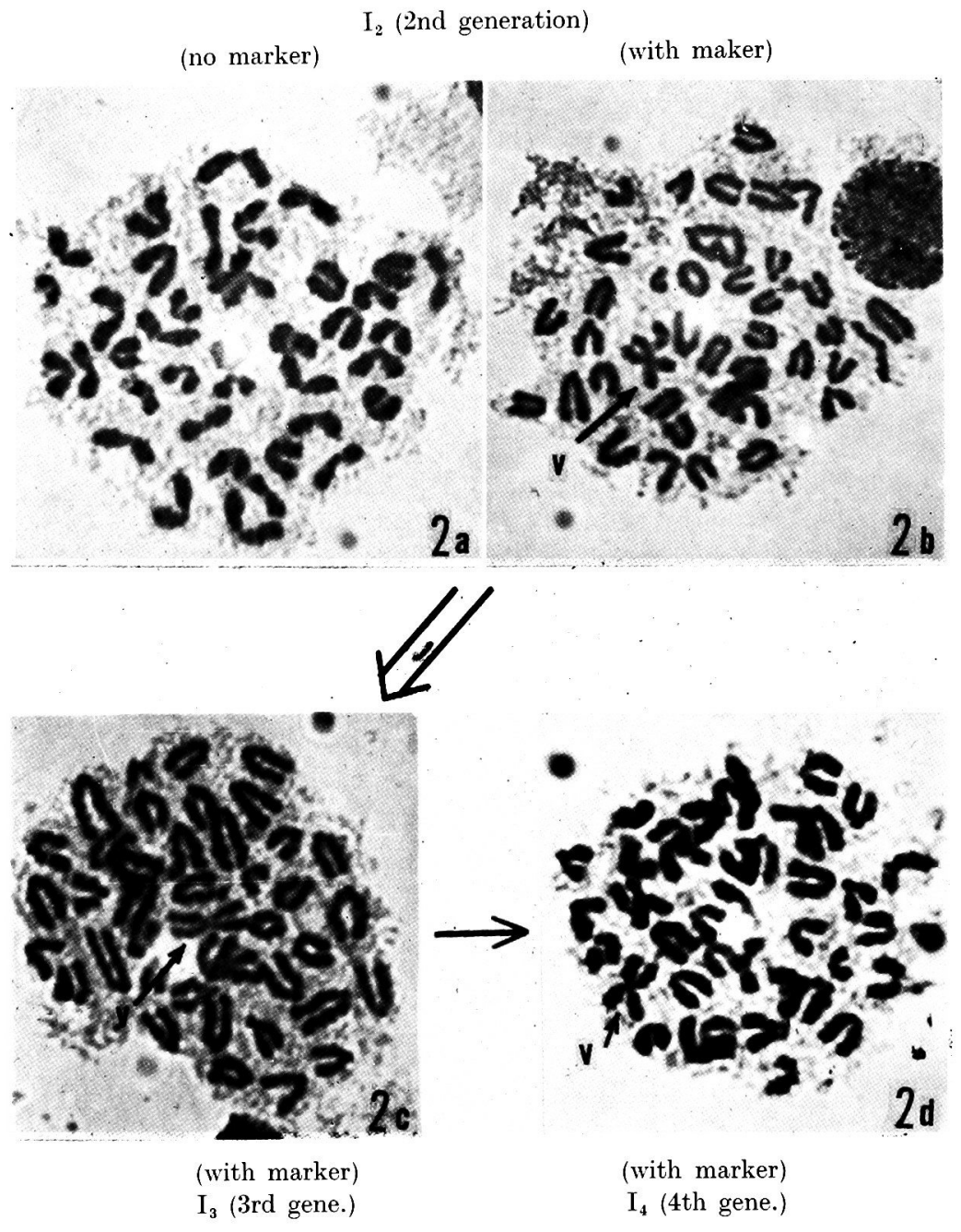

Figs. $2 a-2 d$ 
PLATE 3

8

C3H Trensplant (MA)

generation
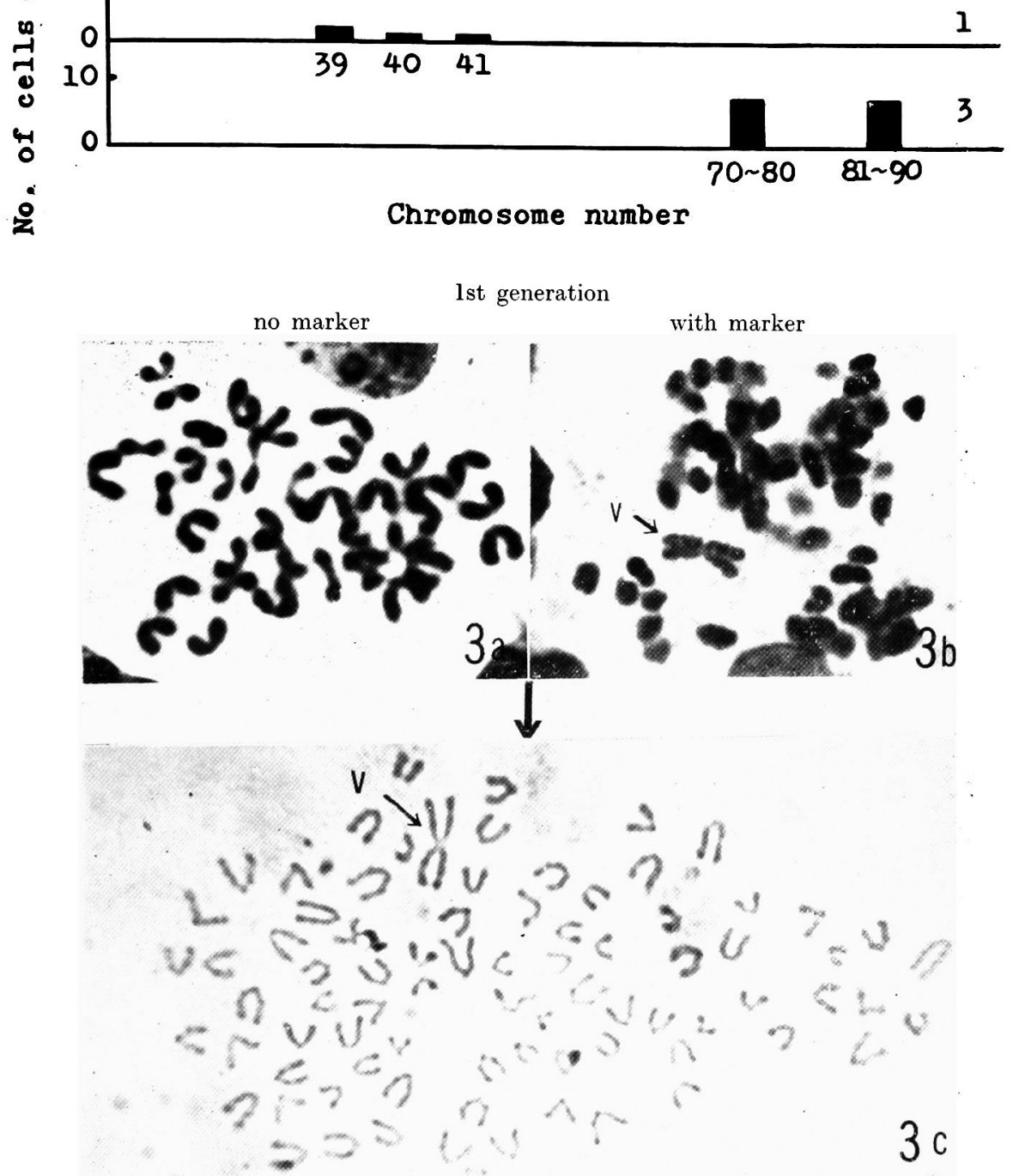

poliploid cell with marker

3rd generation

Figs. 3a-3c 


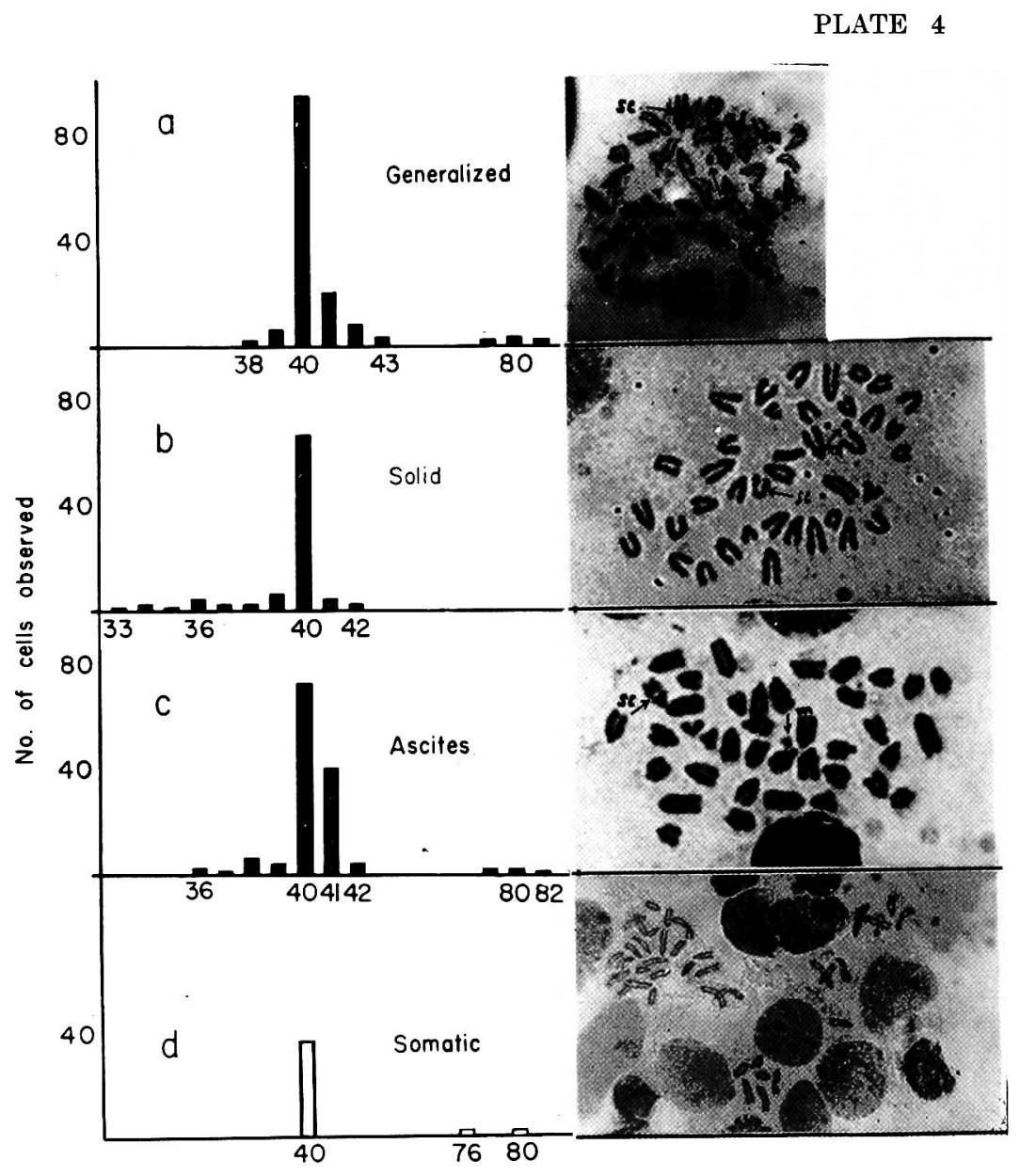

Chromosome number

Figs. $4 a-4 d$ 
PLATE 5
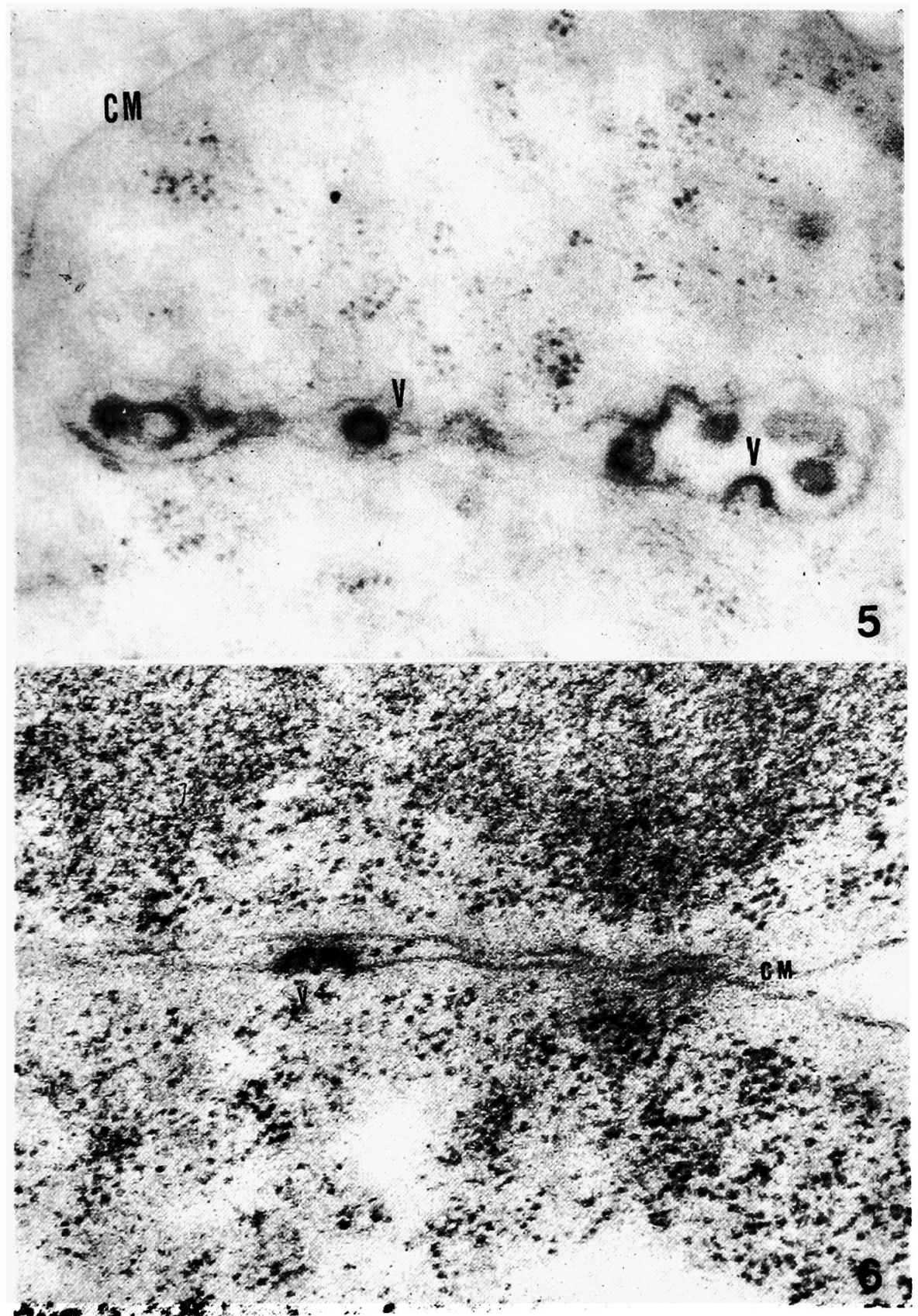

Figs. 5 and 6 
PLATE 6

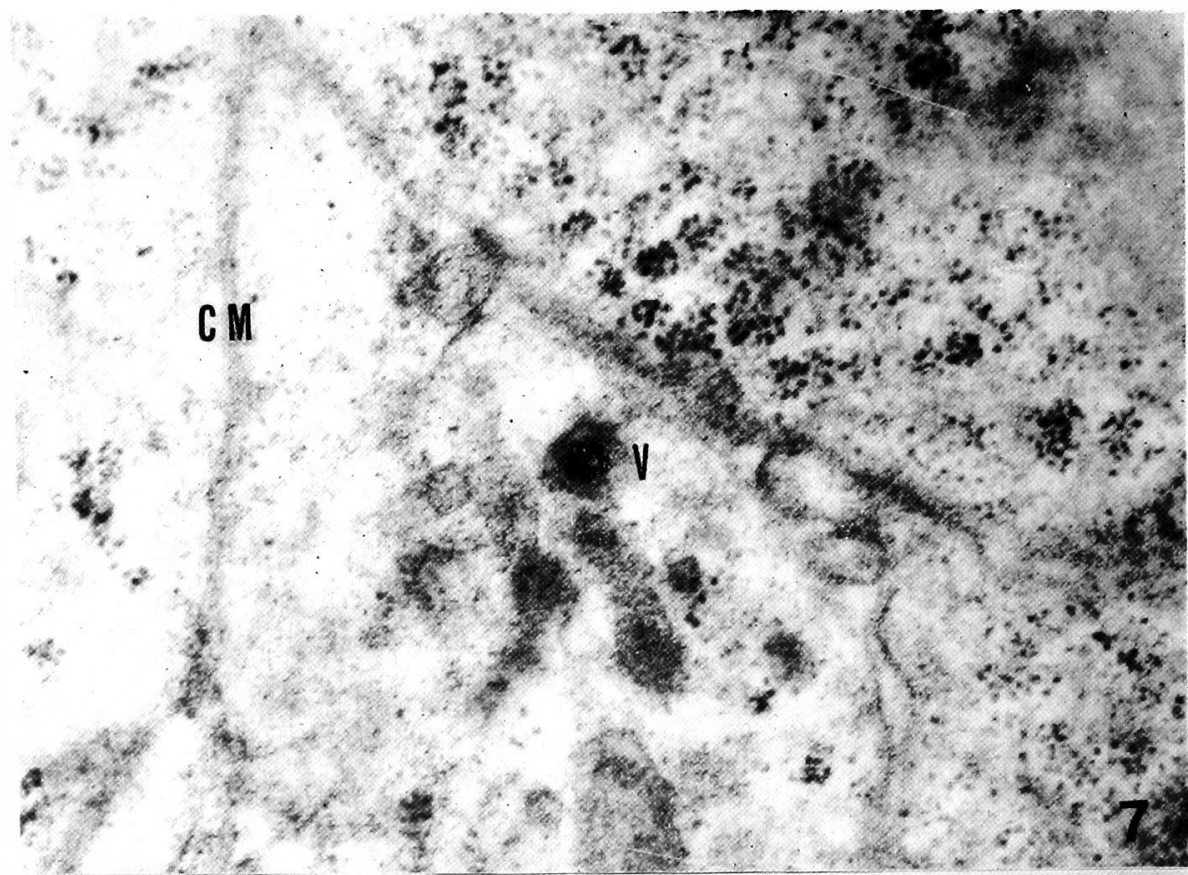
2.

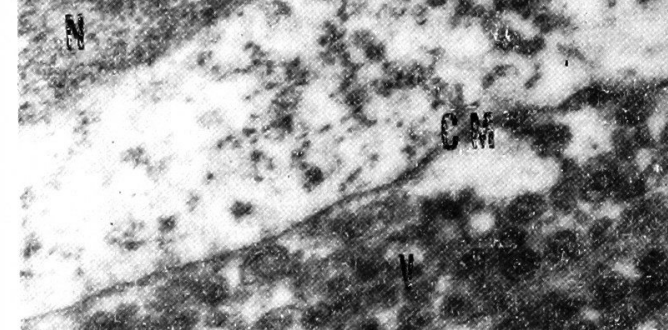

1.20100

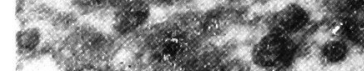
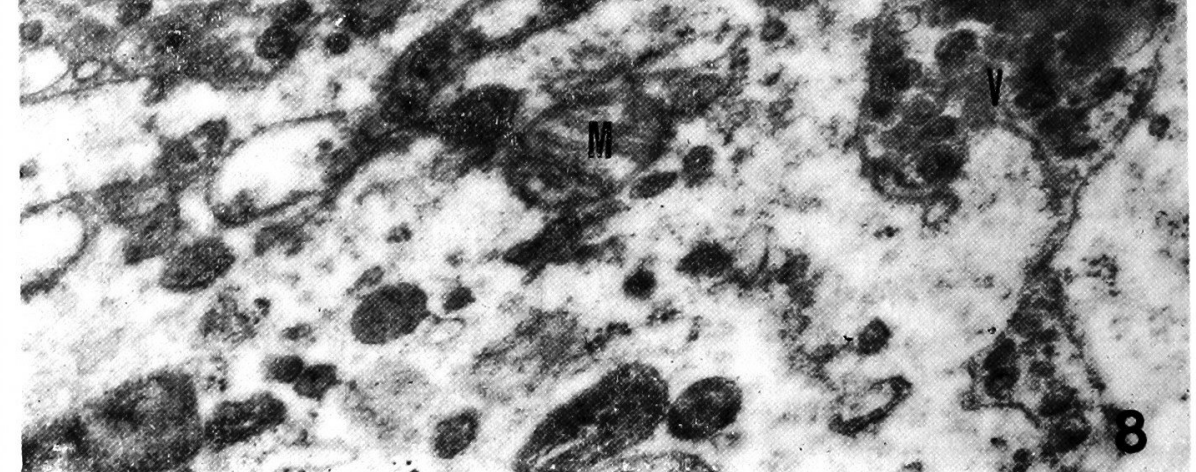

Figs. ' 7 and 8 
PLATE 7

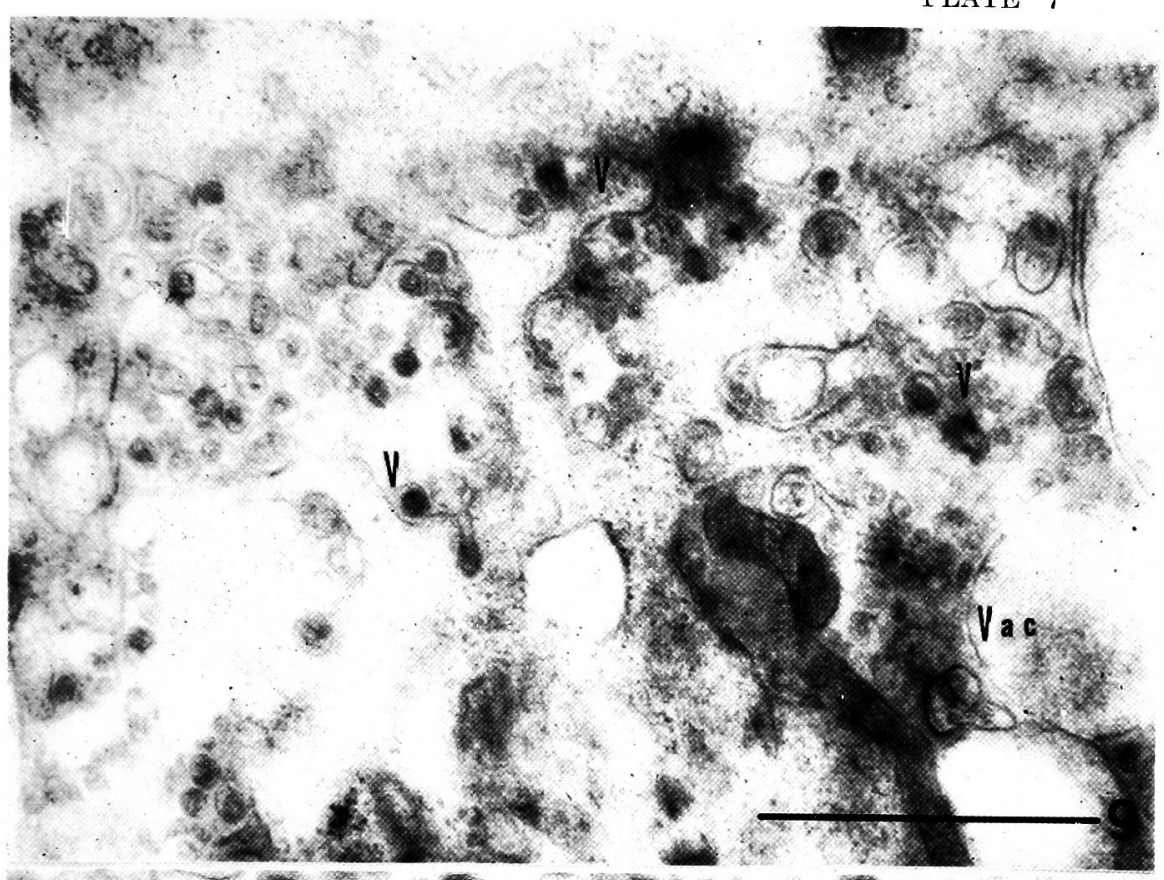

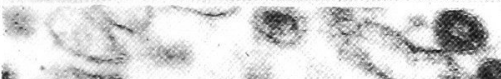

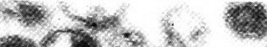
(

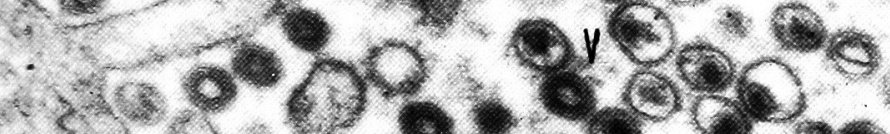

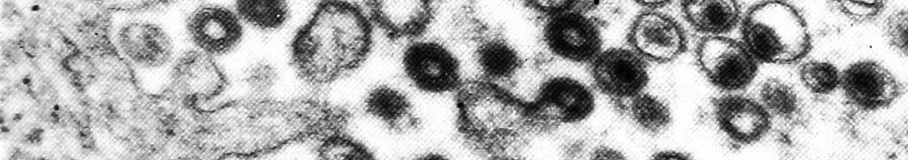
a.

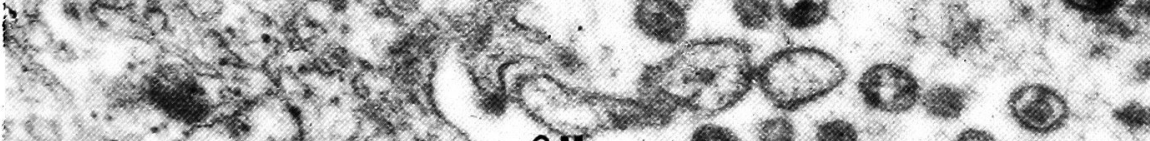

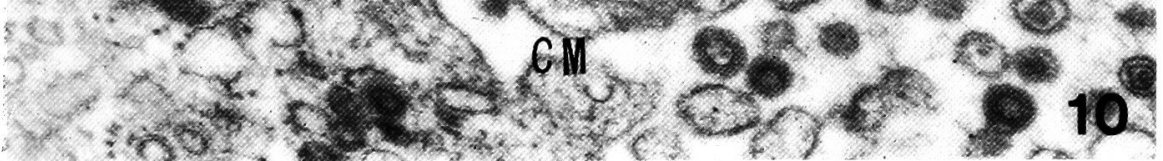

Figs. 9 and 10 
PLATE 8
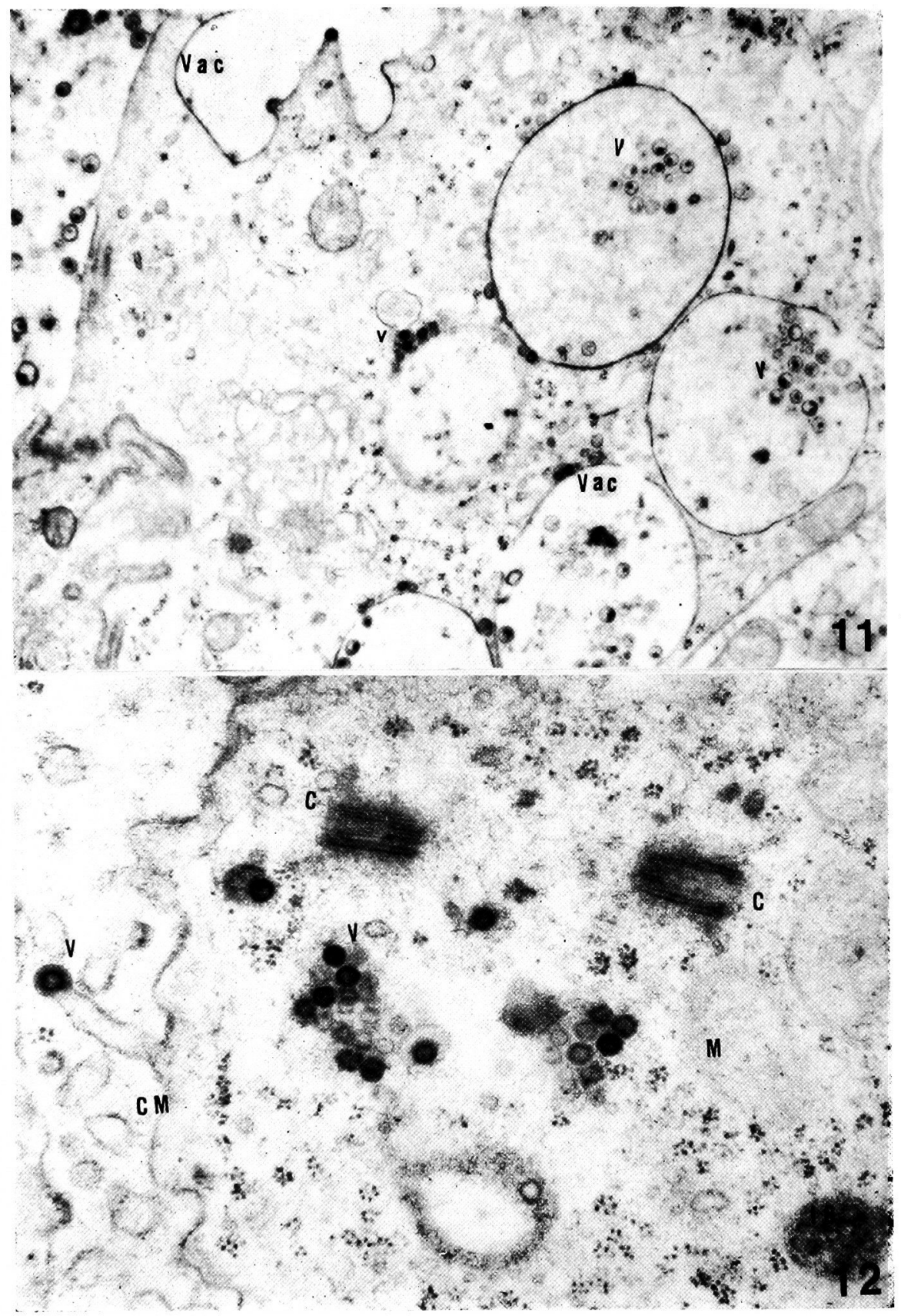

Figs. 11 and 12 
PLATE 9

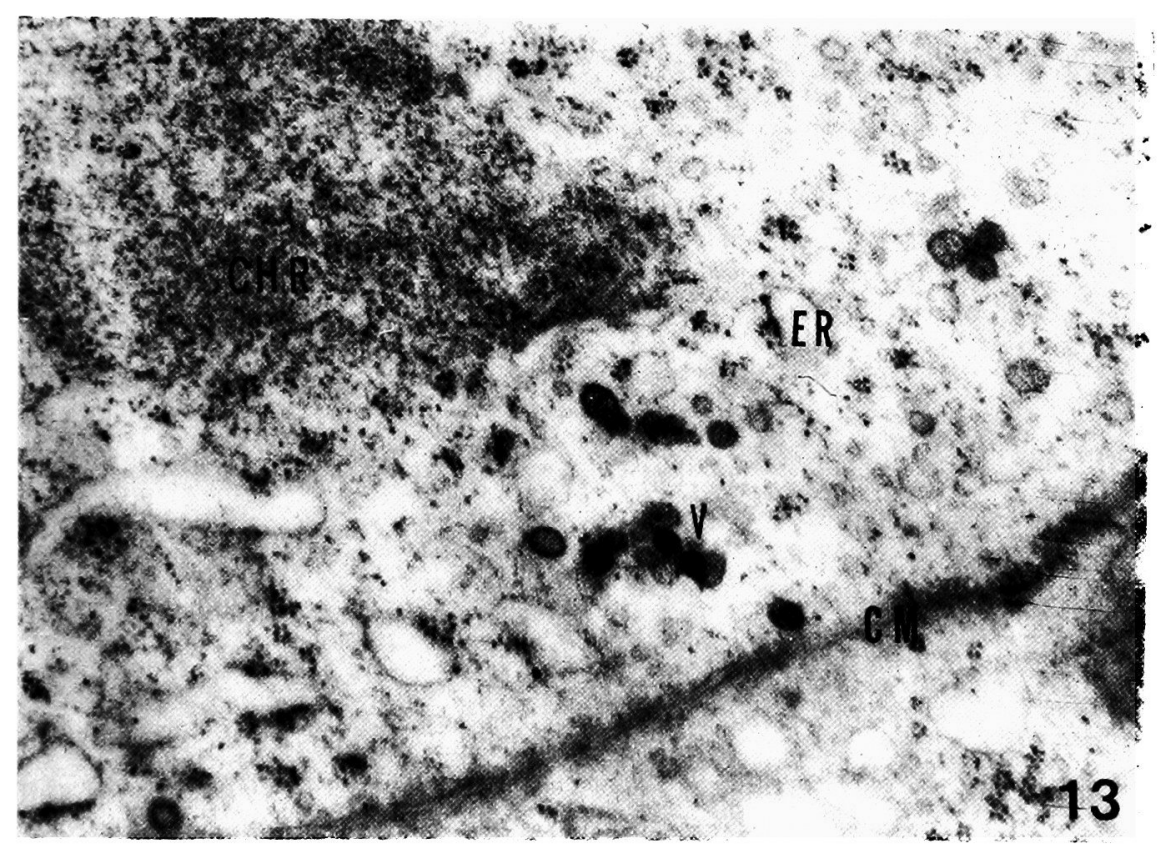

Fig. 13 
PLATE 10

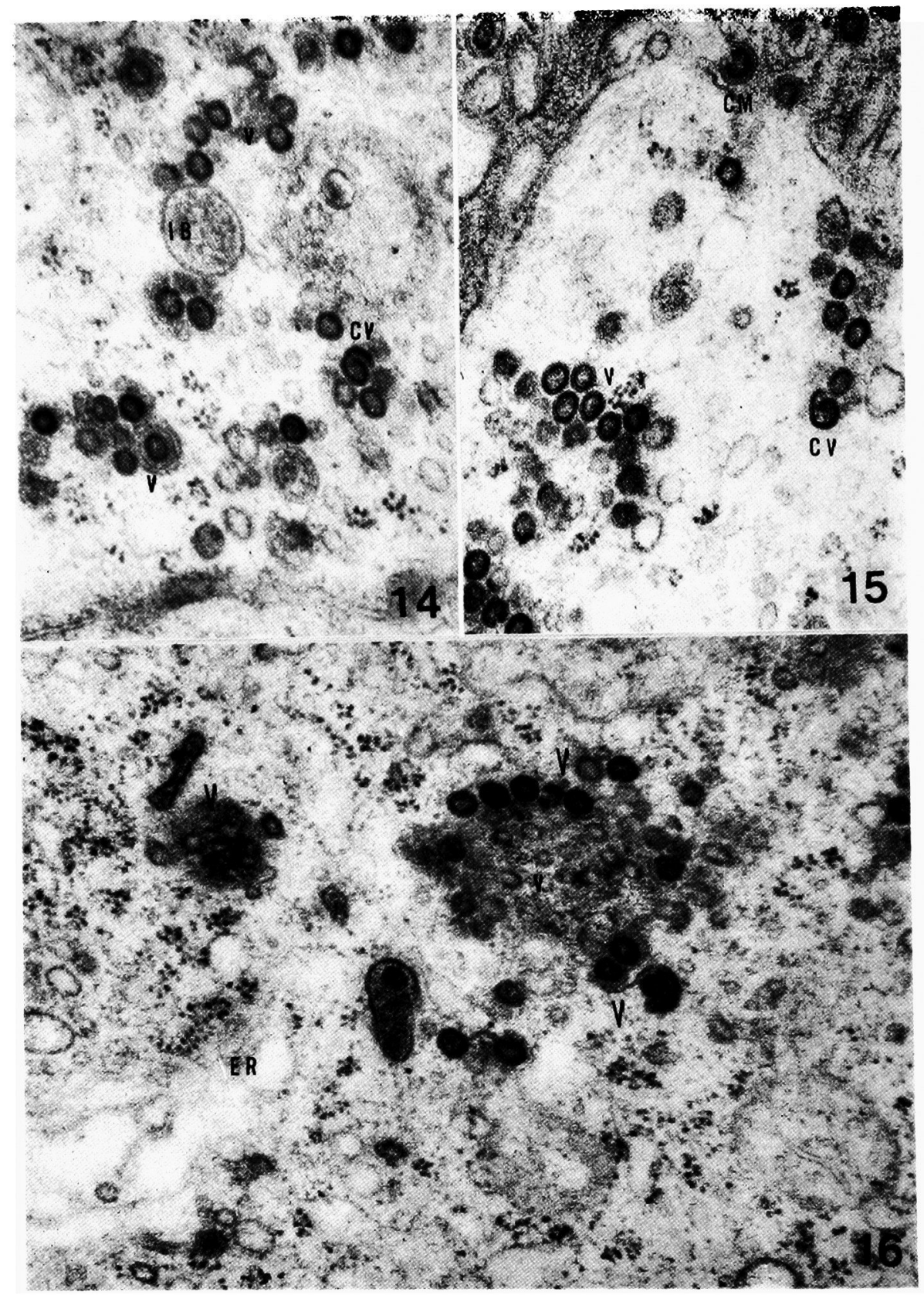

Figs. 14,15 and 16 
PLATE 11

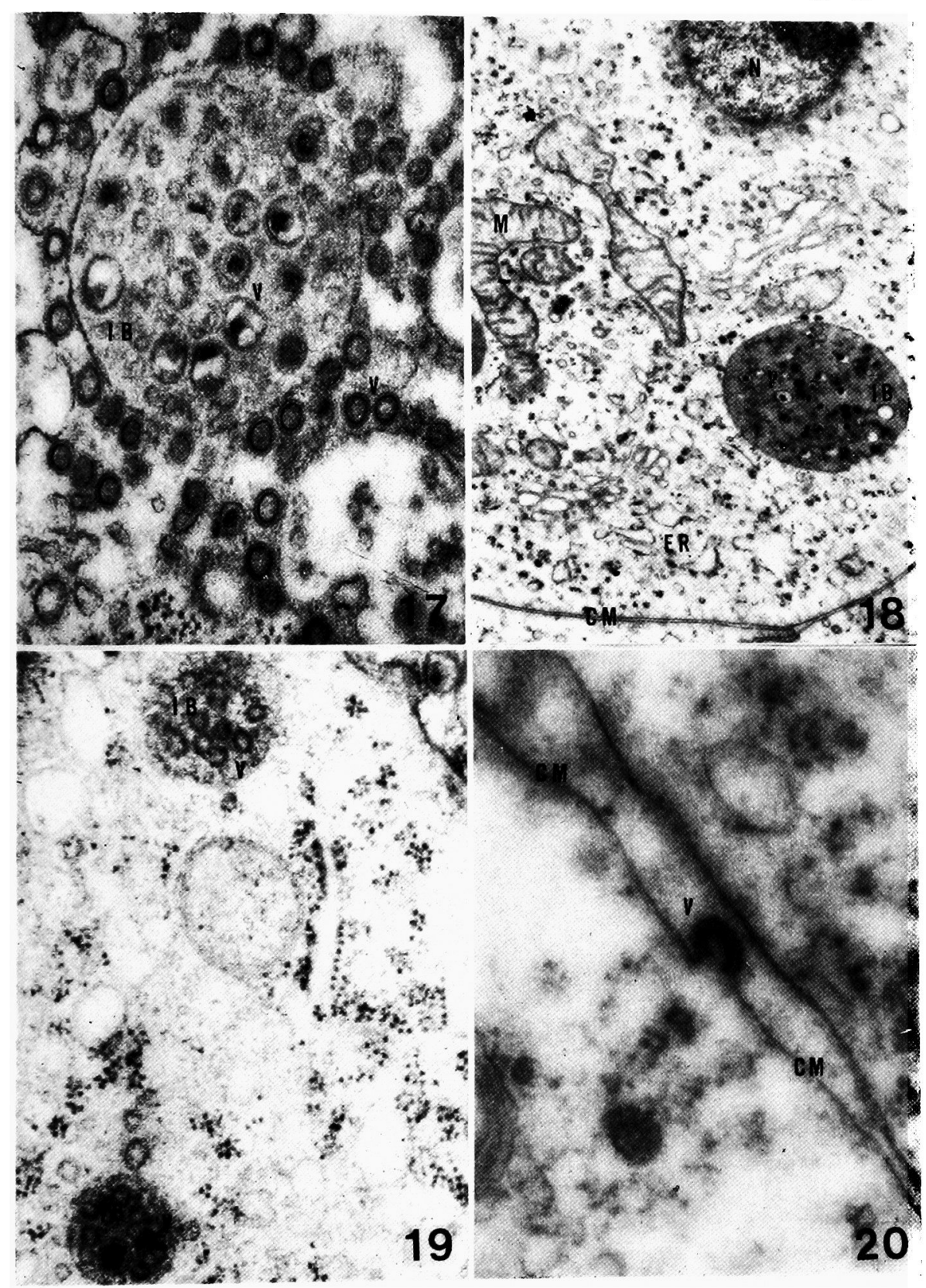

Figs. 17, 18, 19 and 20 
PLATE 12

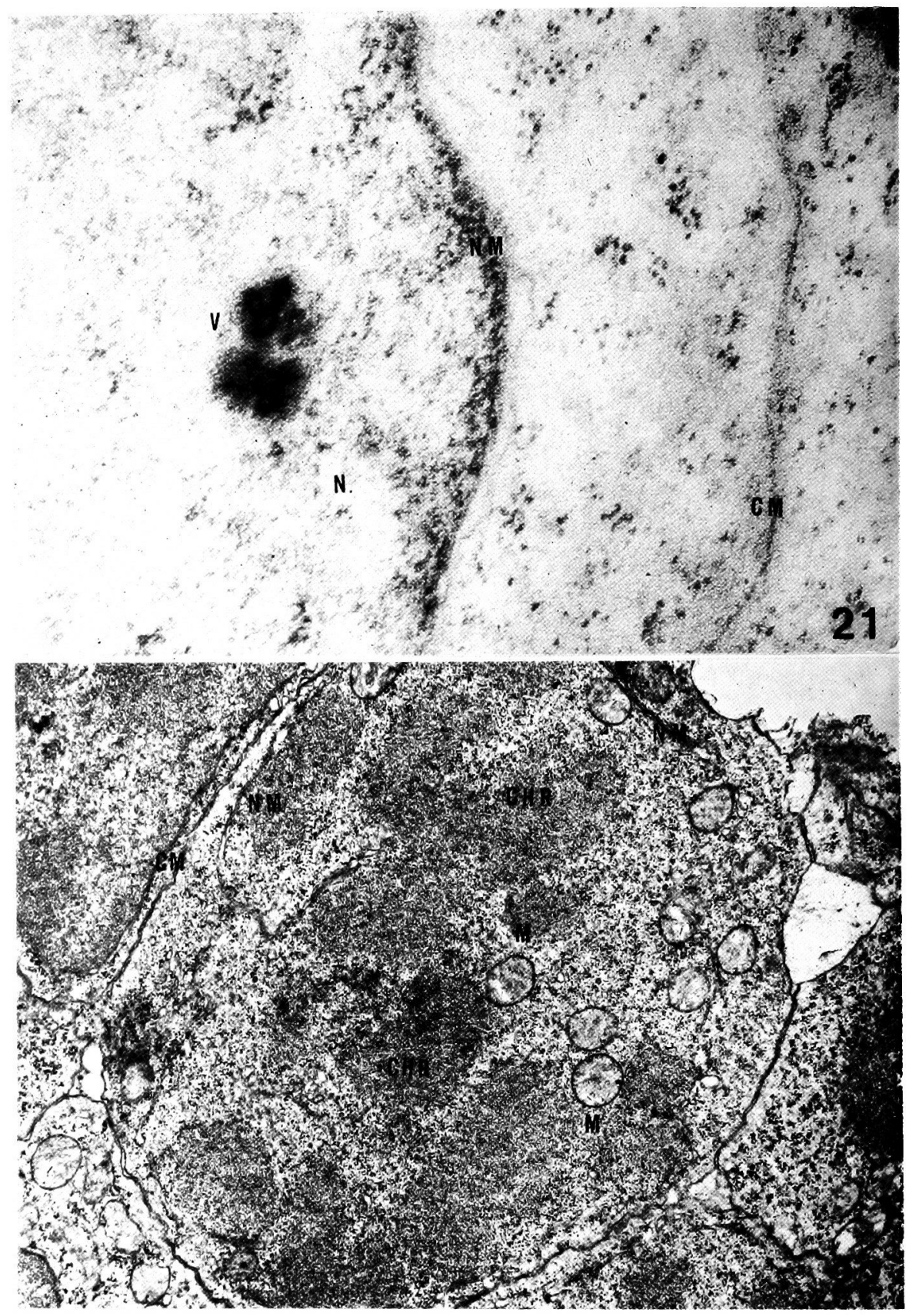

Figs. 21 and 22 
PLATE 13

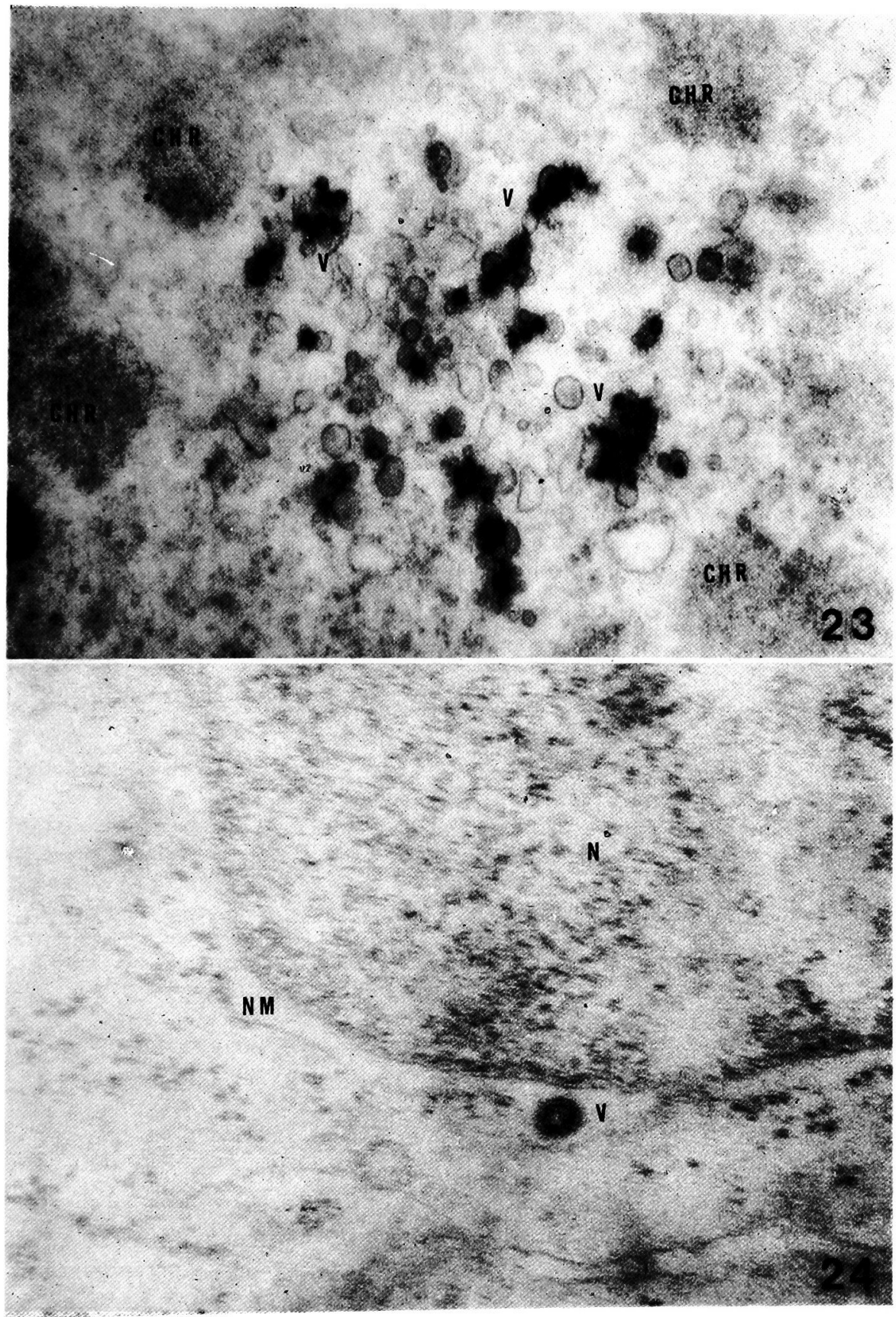

Figs. 21 and 22 
PLATE 14

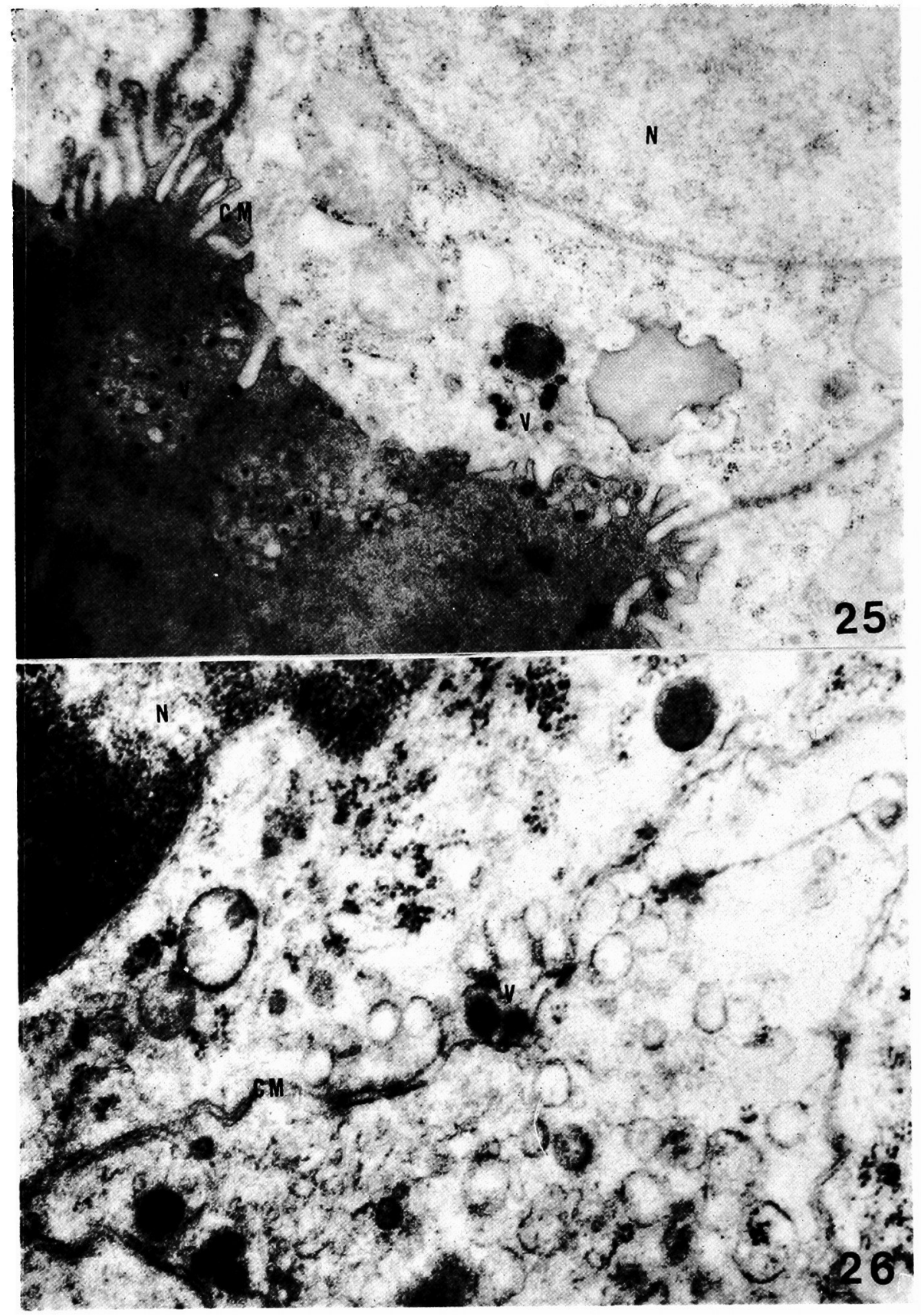

Figs. 25 and 26 